\title{
FUNDACJE XV-WIECZNYCH OLTARZY W KOŚCIELE MARIACKIM W KRAKOWIE I ICH UPOSAŻENIE DO ROKU 1529*
}

Kościół Wniebowzięcia Najświętszej Panny Marii w Krakowie (Mariacki), usytuowany w północno-wschodnim narożniku Rynku, od dawna ceniony był jako jeden $\mathrm{z}$ najznakomitszych przykładów budowli sakralnych w stylu gotyckim w Polsce. Doczekał się też szeregu opracowań czy to w dziełach ogólnie omawiających dzieje Krakowa i jego sztukę, czy też tematycznych artykułach prezentujących zarówno architekturę kościoła, jak i zachowane w jego wnętrzu zabytki sztuki.

Pomimo sporej ilości publikacji w niewielu z nich uwzględniono wyposażenie wnętrza kościoła Panny Marii w ołtarze w okresie średniowiecza. Zasadniczo można jedynie wskazać na opracowania Mariana Friedberga ${ }^{1}$ - z roku 1928 (sygnalizujace fundacje XIV- i XV-wiecznych ołtarzy i wymieniajace altarystów) oraz Edmunda Długopolskiego ${ }^{2}-\mathrm{z}$ roku 1906. Zapewne z dokumentów archiwalnych korzystał także autor starszego opracowania, Wilhelm Gąsiorowski ${ }^{3}$, który omówił fundacje wraz $z$ uposażeniem ołtarzy istniejących w 2. połowie XIX stulecia (uwzględniając legaty z okresu średniowiecza); opracowanie to nie zawiera jednak odwołań do źródeł. Pewną próbę w ukazaniu fundacji ołtarzy podjął też Bolesław Kumor przy okazji omawiania dziejów diecezji krakowskiej do roku $1795^{4}$. Podstawowa jednak dla tego autora stała się - w odniesieniu do kościoła Mariackiego - wizytacja z roku $1711^{\text {s }}$, co też spowodowało ogromne zamieszanie

* Niniejszy artykuł stanowi rozwinięcie tematu średniowiecznych ołtarzy w kościele Panny Marii, uwzględnionego w monografii - zob. E. Piwowarczyk, Dzieje kościola Mariackiego (XIII-XVI w.), Kraków 2000. Pierwsza część opracowania, w której zostały omówione fundacje XIV-wiecznych ołtarzy oraz ich uposażenie do roku 1529 ukazała się w: Charisteria Tito Górski oblata. Studia i rozprawy ofiarowane profesorowi Tytusowi Górskiemu, Kraków 2003, s. 199-217.

${ }^{\prime}$ Zob. M. Fr i e d b e rg, Zatożenie i poczatkowe dzieje kościoła N. Panny Maryi w Krakowie (XIII-XV w.), „Rocznik Krakowski” [cyt. dalej: RK] 2:1928 (nadbitka), s. 1-31.

${ }^{2}$ Zob. E. D ł u g o p o l s k i, Wstęp, [w:] Katalog kościola N.P. Maryi w Krakowie, „Teki Grona Konserwatorów Galicji Zachodniej" 6:1906, s. 1-54. ków 1878

${ }^{3}$ Zob. W. Gą s i or o w sk i, Kościól Archiprezbiterialny N.P. Maryi w Krakowie, Kra-

${ }_{5}^{4}$ Zob. B. K u m o r, Dzieje diecezji krakowskiej do roku 1795, t. 2, Kraków 1999.

${ }^{5}$ Zob. Archiwum Kurii Metropolitalnej w Krakowie [cyt. dalej: AKMKr], Acta Visitationis Capituli 63, p. 1r-113v. 
w informacjach $z$ okresu średniowiecza. Natomiast ostatnio ukazała się książka Jerzego Rajmana ${ }^{6}$, w której autor wymienia krakowskie patrocinia ołtarzy w okresie średniowiecza, wśród nich również i w kościele Panny Marii, wskazując na odnoszące się do wezwań zapisy źródłowe. Analizując owe źródła, podkreślić jednak należy, iż zachowane dokumenty miejskie i parafialne nie zawsze zawieraja jednoznaczną informację odnośnie do fundacji czy uposażenia istniejących przy altariach ministeriów.

Ważniejsze z dokumentów źródłowych dotyczących kościoła Panny Marii w okresie średniowiecza zostały też opublikowane. Wśród nich zaś - w odniesieniu do interesującego nas tematu - na podkreślenie zasługuje Liber beneficiorum Jana Długosza (wzmiankujące fundatorów ołtarzy oraz uposażenia ministeriów około połowy XV wieku) oraz Liber retaxationum ${ }^{8}$ z roku 1529 (odnotowujące uposażenia ministeriów). Natomiast nie doczekała się wydania Wizytacja kościoła Panny Marii z roku 1599, której tekst zaginął przetrwawszy jedynie w odpisie Czesława Skowrona ${ }^{9}$. Wiele informacji na temat fundacji ołtarzy, istniejących przy nich altarii i uposażenia ministeriów, odnaleźć można również w dokumentach przechowywanych zarówno w Archiwum Parafialnym kościoła Mariackiego, jak i w Archiwum Kapituly Metropolitalnej w Krakowie, Archiwum Kurii Metropolitalnej w Krakowie, czy Archiwum Państwowym miasta Krakowa. Niektóre z przechowywanych w tych archiwach dokumentów zostały wydane drukiem, jak w przypadku ksiag miejskich ${ }^{10}$ czy zamieszczone w wydawnictwach ciagłych z zakresu historii kościoła i historii sztuki ${ }^{11}$. Większość jednak, szczególnie gdy

${ }^{6}$ Zob. J. R a j m a n, Średniowieczne patrocinia krakowskie, Kraków 2002, s. 61-68. Autor jednak - jak sam stwierdza - wskazując patrocinia nie podjął próby rozstrzygnięcia, czy odnoszą się one do ołtarza, czy istniejącej przy nim altarii. Zaznaczył tylko, iż wezwanie ,występuje przy ołtarzu" (tamże, s. 14), co miejscami znacznie utrudnia identyfikację wezwania ołtarza bądź tylko ministerium. Podobną trudność stanowi umieszczenie informacji odnoszących się do jednakowych patrociniów pod jednym, wspólnym tytułem, co sugerowałoby, iż występują one tylko raz. Tymczasem niektóre $z$ wezwań (np. Wniebowzięcia NPM) pojawiają się kilka razy, zarówno jako wezwania ołtarzy, jak i altarii i związanych z nimi ministeriów.

${ }^{7}$ Zob. [J. Dłu g o s z], Liber beneficiorum dioecesis Cracoviensis [cyt. dalej: LB], t. 2, wyd. A. Przeździecki, Kraków 1864, s. 2-5.

${ }^{8}$ Zob. Księga dochodów beneficjów diecezji krakowskiej z r. 1529 (tzw. Liber retaxationum), wyd. Z. Leszczyńska-Skrętowa, Wrocław-Warszawa-Kraków 1968.

${ }^{9}$ Zob. Wizytacje krakowskie 1599, oprac. C. Skowron, cz. 2, s. 260-385 [maszynopis w posiadaniu autora].

${ }^{10}$ Zob. m.in.: Kodeks dyplomatyczny miasta Krakowa [cyt. dalej: KDK], t. 1-2, wyd. F. Piekosiński, Kraków 1879-1882; Kodeks dyplomatyczny katedry krakowskiej ś. Wacława [cyt. dualej: KKX], i. i-2, wyd. F. Piekosiński, Kraków i $874-\mathbf{i} 8 \hat{3} \hat{3}$; Najstarsze ksstęgı l rachunkı miasta Krakowa od r. 1300 do 1400 [cyt. dalej: NKiRMK], cz. 1-2, wyd. F. Piekosiński, J. Szujski, Kraków 1877-1878.

${ }^{11}$ Zob. m.in.: Zbiór dokumentów katedry i diecezji krakowskiej [cyt. dalej: ZDKK], cz. 1-2, wyd. S. Kuraś, Lublin 1965-1973; Cracovia artificum 1300-1500 [cyt. dalej: CA 1], wyd. J. Ptaśnik, Kraków 1917 (Źródla do historii sztuki i cywilizacji w Polsce, t. 4); Cracovia artificum 1501-1550 [cyt. dalej: CA 2], wyd. J. Ptaśnik, z 1: Kraków 1936, z. 2: Kraków 1937, z 3: Kraków 1948 (Źródla do historii sztuki i cywilizacji w Polsce, t. 5); Cracovia artificum. Suplementa. Teksty źródlowe do dziejów kultury $i$ sztuki z archiwów kurialnych i kapitulnych w Krakowie 1433-1440, wyd. B. Przybyszewski, Kraków 1988 [cyt. dalej: CA Supl. 1433-1440]; Cracovia artificum. Suplementa. Krakowskie środowisko artystyczne czasów Wita Stwosza, wyd. B. Przy* byszewski, Kraków 1990 [cyt. dalej: CA Supl.Kr]. 
chodzi o dokumenty przechowywane w Archiwum Parafialnym kościoła Mariackiego, jak do tej pory, nie została bliżej opracowana. Tymczasem, zestawiając zawarte w nich informacje, możliwym staje się ukazanie wyposażenia wnętrza kościoła Panny Marii w ołtarze w XV wieku wraz z uposażeniem istniejących przy altariach ministeriów.

\section{FUNDACJE OLTARZY W 1, POEOWIE XV WIEKU}

Już w poprzednim, XIV stuleciu kościół Panny Marii uzyskał znaczne wyposażenie wnętrza w ołtarze, których pod koniec tego stulecia było - wraz z ołtarzem głównym - jedenaście ${ }^{12}$. Kolejne legaty uczynione na fundację nowych ołtarzy napłynęły w 1 . połowie XV stulecia.

Jako jeden z pierwszych sprawiono jeszcze przed rokiem 1419 ołtarz poświęcony Św. Marii Magdalenie (S. Mariae Magdalenae), ustawiony przy środkowym filarze poludniowej nawy ${ }^{13}$. W tym bowiem roku (1419) przy owym ołtarzu, z legatu Jakuba Rolle, uposażono I ministerium ${ }^{14}$; powiększone zostało zapisem Mikołaja Rolle de Vgest w roku $1425^{15}$. Według Jana Długosza, patronat nad owym I ministerium altarii ku czci śś. Marii Magdaleny, Marty i Lazarza, sprawowali rajcy krakowscy, którzy też prezentowali na stanowisko altarysty jednego $\mathrm{z}$ wikarych kościoła Panny Marii; $\mathrm{z}$ ich zapewne wyboru altarystą był wówczas Grzegorz z Sacza ${ }^{16}$. Natomiast II ministerium przy ołtarzu Św. Marii Magdaleny, zwanym również Męki Pańskiej (Passionis Domini), legowano zapisem testamentowym Mikołaja Zatorskiego; erygowane w roku 1521, uposażone zostało czynszem rocznym 12 grzywien zabezpieczonym na dobrach Chełm ${ }^{17}$. Istnienie przy ołtarzu Św. Marii Magdaleny dwóch ministeriów potwierdzono również w Liber retaxationum z roku 1529 . Odnotowano w niej, iż altarystą I ministerium był Jan Cerdonis z Krakowa, altaria zaś uposażona była na wsiach Pieczongi i Strzelce. Natomiast altarystą II ministerium był Mikołaj z Krakowa, czerpiący $\mathrm{z}$ racji funkcji uposażenie $\mathrm{z}$ dóbr Chełm ${ }^{18}$.

Drugim, ufundowanym również przed rokiem 1419, był ołtarz Św. Benedykta (S. Benedicti), który ustawiono przy ścianie północnej nawy bocznej, po-

12 Zob. E. P i wowarczyk, Fundacje XIV-wiecznych ottarzy w kościele Mariackim w Krakowie i ich uposazenie do roku 1529, [w:] Charisteria Tito Górski..., dz. cyt., s. 199-217.

${ }^{13}$ Zob. $\mathrm{t}$ a ż, Dzieje..., dz. cyt., s. 142; por. J. R a j m a n, Sredniowieczne patrocinia..., dz. cyt., s. 65 (autor wzmiankuje jednak pierwsze źródło odnośnie do tego ołtarza dopiero z roku 1433). Zob. też: B. K u m o r, Dzieje..., dz. cyt., s. 543, tabela 81. Bolesław Kumor datuje jednak fundację ołtarza ku czci Męki Pańskiej i św. Marii Magdaleny na przed rokiem 1470; na ten sam czas wskazuje również uposażenie przy altarii I ministerium z fundacji jakiegoś mieszczanina krakowskiego. Wymieniony jednak przez Kumora ołtarz z podwójnym wezwaniem to w rzeczywistości dwa różne ołtarze, chociaż ustawione przy tym samym filarze kościoła.

${ }_{14}$ Zob. KDK 2, nr 406.

${ }^{15}$ Zob. tamże, nr 510.

${ }^{16}$ Zob. LB 2, s. 3.

${ }^{17}$ Zob. Archiwum Parafialne kościoła Mariackiego [cyt. dalej: APkM], dypl. nr 96 (166, 167), 97(168, 169, 170); por. tamże, vol. 45, fasc. A. Por. B. K u m or, Dzieje.., s. 543, tabela 81 (autor wymienia jednak jako fundatora uposażenia II ministerium Michała Zatorskiego).

${ }^{18}$ Zob. Ksiega dochodów..., s. 121, 138; por. Wizytacje.., s. 330-332. 
między wejściami do kaplicy Św. Marka a kruchtą ${ }^{19}$. Według przekazu Jana Długosza, patronat nad I ministerium tego ołtarza, altarii ku czci św. Benedykta, znajdował się w posiadaniu rajców krakowskich. Zamianowali oni na to stanowisko Jana z Oświęcimia, doktora dekretów, czerpiącego uposażenie z racji funkcji $\mathrm{z}$ dóbr Oświęcim ${ }^{20}$. II ministerium przy tym ołtarzu ufundowane zostało $w$ roku 1481 z zapisu Zaifreda, rajcy krakowskiego, który też uposażył je na wsi Witowi$\mathrm{ce}^{21}$. Natomiast w roku 1502, na mocy zapisu Macieja Mydlarza i Jana Russka, mieszczan krakowskich, wykonawców testamentu Jakuba ,de Bambelno”, uposażono przy oltarzu Św. Benedykta III ministerium altarii ku czci św. Fabiana i Sebastiana; erygowane w roku 1505 uposażone zostało czynszem rocznym 20 grzywien zabezpieczonym na dobrach Marchocice i Morsko (Mokrsko) ${ }^{22}$. W roku 1529 altarystą tego ministerium był Marek z Kurzelowa, czerpiący nadal z racji funkcji uposażenie ze wsi Marchocice i Mokrsko. Natomiast II ministerium, którego altarystą był ,,de Hazlach”, uposażały dobra wsi Witowice ${ }^{23}$.

Prawdopodobnie też w początkach lat dwudziestych XIV stulecia, jeszcze przed rokiem 1423 sprawiono do kaplicy w przyziemiu wieży północnej nowy oltarz ku czci św. Stanisława (S. Stanislai) ${ }^{24}$; altarystę bowiem oltarza pod takim

${ }^{19}$ Zob. J. R a j ma n, Średniowieczne patrocinia.., dz. cyt., s. 62. Jerzy Rajman podaje też - jako pełne - wezwanie ołtarza: śś. Benedykta Opata, Modesta, Sebastiana i Fabiana, Zofii i Korduli. Wydaje się jednak, iz jest to wezwanie któregoś z ministeriów, ołtarz zaś jako taki poświęcony był tylko Św. Benedyktowi - por. E. P i wo w a r c z y k, Dzieje..., dz. cyt., s. 145. Zob. też: B. K u mo r, Dzieje..., dz. cyt., s. 547. Bolesław Kumor wzmiankuje jednak omawiany ołtarz jako ŚŚ. Floriana i Sebastiana Męczenników oraz Benedykta Opata i datuje jego wykonanie na przed rokiem 1470; wówczas też miano uposażyć przy nim I ministerium. Na innym miejscu swojego opracowania wskazuje również na inny ołtarz ŚŚ. Benedykta i Mikołaja, jako sprawiony na początku XVI wieku, tabelę zaś wyliczająca istniejące przy nim ministeria tytułuje: „ministeria w kaplicy ŚŚ. Benedykta i Mikołaja” - zob. tamże, s. 553, tabela 91. Nie była to oczywiście kaplica, lecz ołtarz, podane zaś w tabeli uposażenia ministeriów odnoszą się do ołtarza Św. Benedykta - zapisanego przez Kumora jako ŚŚ. Floriana i Sebastiana. Nigdy też w kościele Mariackim nie było ołtarza ufundowanego ku czci św. Floriana, był natomiast sprawiony przed rokiem 1529 ołtarz ku czci śś. Fabiana i Sebastiana.

${ }^{20}$ Zob. LB 2, s. 5. Por. B. K u mo r, Dzieje..., dz. cyt., s. 547. Tam też Bolesław Kumor podaje dwie daty uposażenia I ministerium: przed rokiem 1470 oraz w roku 1481 przez Zeifreda rajcę krakowskiego; ministerium to uposażał czynsz 12 grzywien zabezpieczony na jatce rzeźniczej Lorenga na Kleparzu. W innym też miejscu (zob. tamże, s. 553, tabela 91) datuje uposażenie I ministerium na rok 1512 .

${ }^{21}$ Zob. APkM, vol. 45, fasc. A. Por. B. Ku mor, Dzieje..., dz. cyt., s. 553, tabela 91. Wprawdzie Bolesław Kumor nie podaje ani daty fundacji, ani fundatora uposażenia II ministerium, wskazuje natomiast, iż opiewało ono na 12 grzywien.

${ }^{22}$ Zob APkM, dypl. nt 76(134 ; 135), 80(139). Por. B. Kumor, Dzinje..., dz cyt, s. 553, tabela 91. Tam też Bolestaw Kumor wzmiankuje jako fundatora uposażenia III ministerium altarii ku czci śś. Bendykta, Fabiana i Sebastiana - Mikołaja Czipsara (Pelcza), rok zaś fundacji ustala na 1418.

${ }_{23}^{23}$ Zob. Księga dochodów..., dz. cyt., s. 117, 168; por. Wizytacje..., dz. cyt., s. 350-353.

${ }^{24}$ Zob. E. P i w ow a r c z y k, Dzieje..., dz. cyt., s. 132; por. J. R a j m a n, Średniowieczne patrocinia.., dz. cyt., s. 66 (gdzie autor wspomina pod rokiem 1423 kaplicę Św. Stanisława, dziesięć lat zaś później (1433) altarię ołtarza Św. Stanisława). Zob. też: B. K u mo r, Dzieje..., dz. cyt., s. 556-557. Co prawda Bolesław Kumor wymienia ołtarz Sw. Stanisława Biskupa i Męczennika, aczkolwiek przy okazji omawiania ołtarza Św. Katarzyny. Na innym też miejscu wzmiankuje nieznany ołtarz w kaplicy Słowikowskich (a zatem właśnie ołtarz Sw. Stanisława), przypisując mu I ministerium odnoszące się do ołtarza Sw. Katarzyny. 
wezwaniem - w osobie niejakiego Andrzeja z Biecza - zapisano w dokumencie $\mathrm{z}$ roku $1423^{25}$. I ministerium przy ołtarzu Św. Stanisława erygował biskup krakowski Zbigniew Oleśnicki w roku $1432^{26}$. Według Jana Długosza, patronat nad I ministerium altarii ku czci śś. Stanisława i Wacława należał do rajców krakowskich, którzy także uposażali altarię; z ich zapewne prezenty altarystą był wówczas niejaki Eulogius ${ }^{27}$. Rajcy krakowscy uposażali też altarię w roku 1529, kiedy to altarystą był Kraus (Mikołaj, magister artium) ${ }^{28}$.

Kolejny ołtarz, dedykowany ŚŚ. Szymonowi i Judzie Apostolom (Sanctis Simoni et Judae Apostolis), sprawiono jeszcze przed rokiem 1425, ustawiając go przy trzecim filarze (licząc od prezbiterium) po stronie północnej nawy ${ }^{29}$. W tym bowiem roku (1425) w dokumentach odnotowano altarystę tego oltarza w osobie niejakiego Mikołaja Seyfrida ${ }^{30}$. II ministerium przy ołtarzu ŚŚ. Szymona i Judy ufundowano na mocy zapisu testamentowego Jana Stolle (z Głogowa na Śląsku) $\mathrm{z}$ roku $1454^{31}$. Uposażono je w roku 1460 na czynszu wyderkaufowym z Jasienia, patronat zaś nad ołtarzem otrzymali spadkobiercy Jan Swedniczara; na stanowisko altarysty zamianowano wówczas magistra Jana Zaszkowskiego ${ }^{32}$. W wyniku tych zmian Jan Długosz odnotował w Liber beneficiorum istnienie przy ołtarzu ŚŚ. Szymona i Judy dwóch ministeriów. Prawo mianowania na jedną altarię przysługiwało rajcom krakowskim i oni też uposażali ją z kasy miejskiej; $z$ ich zapewne wyboru altarystą był wówczas Hieronim Wolff. Druga altarią rozporzadzał Swedniczar i była ona uposażona ,in villa” (Jasień) ${ }^{33}$. W roku 1473 ołtarz ŚŚ. Szymona i Judy znajdował się też pod patronatem Mikołaja z Białego Zamku ${ }^{34}$. Natomiast jeszcze przed rokiem 1529 uposażono III ministerium przy tym ołtarzu, którego istnienie zanotowano w Liber retaxationum. W roku 1529 altarystą III ministerium był bliżej nieokreślony doktor dekretów, czerpiący uposażenie z racji funkcji ze wsi Dalewicze. Altarystą I ministerium był Stanisław z Łowicza, który czerpał uposażenie z żup wielickich, altarystą zaś na nowo uposażonego II ministerium Wincenty $z$ Krakowa; altaria II ministerium uposażona była na Okocimiu ${ }^{35}$.

\footnotetext{
${ }^{25}$ Zob. KDK 2, nr 506.

${ }^{26}$ Zob. APkM, vol. 61, fasc. 192, nr 5.

${ }^{27}$ Zob. LB 2, s. 4.

${ }^{28}$ Zob. Księga dochodów..., dz. cyt., s. 55; por. Wizytacje.., dz. cyt., s. 341-342.
}

${ }^{29}$ Zob. E. P i w o w a r c z y k, Dzieje..., dz. cyt., s. 142; por. J. R a j m a n, Średniowieczne patrocinia.., dz. cyt., s. 67. Jerzy Rajman wymienia jednak jako pierwsze źródło odnoszące się do tego ołtarza dokument $z$ roku 1470, fundatora zaś upatruje w osobie Mikołaja Schonbergera, notariusza królowej i miejskiego. Ów zaś był jedynie egzekutorem testamentu Jana Stolle notariusza miejskiego, który uposażył II ministerium. Zob. też: B. K u m o r, Dzieje..., dz. cyt., s. 547 , tabela 85 (tam też autor datuje fundację ołtarza na przed rokiem 1475, uposażenie zaś I ministerium na rok $1440(1 ?))$.

${ }^{30}$ Zob. KDK 2, nr 509.

${ }^{31}$ Zob. tamże, nr 439.

${ }^{32}$ Zob. tamże, nr 452. Por. J. R a j m a n, Średniowieczne patrocinia..., dz. cyt., s. 67 (autor jednak myli fundację ministerium z fundacją ołtarza); zob. B. K u m o r, Dzieje..., dz. cyt., s. 547 , tabela 85 (tam też autor datuje fundację uposażenia II ministerium przez Jana Stolle na przed rokiem 1470$)$

${ }^{33}$ Zob. LB 2, s. 4.

${ }^{34}$ Zob. J. R aj m a n, Sredniowieczne patrocinia..., dz. cyt., s. 67.

${ }^{35}$ Zob. Księga dochodów..., dz. cyt., s. 159, 183, 304. Zob. tez: APkM, vol. 45, fasc. A; por. Wizytacje..., dz. cyt., s. 339-341. 
Z kolei w roku 1430 w źródłach zapisano już informację o uposażeniu czynszem rocznym 10 grzywien, sumptem Piotra Edlingera, I ministerium altarii ku czci śś. Tomasza Apostoła, Tomasza z Akwinu i Tomasza z Kantuaryjskiego, przy ołtarzu poświęconemu Św. Tomaszowi Apostolowi (S. Thomee Apostoli); altarystą był wówczas (do 1440) niejaki Jan Hesse ${ }^{36}$. Ołtarz ten istniał zatem przed wspomnianym rokiem 1430, będąc ustawionym przy południowej nawie bocznej, pomiędzy trzecim a czwartym oknem (licząc od prezbiterium) ${ }^{37}$. Dziesięć lat później (1440) patronat nad oltarzem sprawował - razem z Piotrem Edlingerem - Mikołaj Proczkinhan ${ }^{38}$. Natomiast w czasie spisywania Liber beneficiorum patronat nad ołtarzem Św. Tomasza należał już do Langstanowej z Krakowa i jej babki, altarystą zaś był Jan, proboszcz z Wolborza ${ }^{39}$. Kolejne, II ministerium przy ołtarzu Św. Tomasza ufundowano jeszcze przed rokiem 1529. Wedhug zapisu w Liber retaxationum $\mathrm{z}$ roku 1529 , uposażone było na jednej jatce rzeźniczej oraz wójtostwie z Kazimierza i jednej jatce rzeźniczej w Krakowie. Natomiast altarysta I ministerium, którym był wówczas doktor dekretów Filip, czerpał uposażenie z racji funkcji z czynszu z domu Jana Hallera (drukarza) ${ }^{40}$.

Dwa lata później (1432) światynia wzbogaciła się o następny ołtarz, który ustawiono przy poludniowej ścianie nawy bocznej, pomiędzy pierwszym a drugim oknem (licząc od prezbiterium) ${ }^{41}$. Ufundowano go $z$ zapisu Piotra Kaldenberga, a jego erygowania ku czci Nawiedzenia NPM (Visitationis B.M.V.) dokonał w roku 1433 biskup krakowski Zbigniew Oleśnicki ${ }^{42}$. Zgodnie z zapisem Jana Długosza w Liber beneficiorum, patronat nad tym ołtarzem sprawowała niejaka Katarzyna z Krakowa ze swoimi przyjaciółmi, a uposażenie altarii, której altarystą był Jan Creydlar z Krakowa, czerpano ze wsi Karniów ${ }^{43}$. Być może jednak, iż uposażenie tej altarii już pod koniec XIV wieku zanikło, jako że nie odnotowano takowego w Liber retaxationum $\mathrm{z}$ roku 1529.

Jeszcze około roku 1433 wykonano też oltarz poświęcony Św. Annie (S. Annae), ustawiony przy trzecim filarze poludniowej nawy (licząc od prezbite-

${ }^{36}$ Zob. KDK 2, nr 414.

${ }^{37}$ Zob. E. P i w o w a r c z y k, Dzieje..., dz. cyt., s. 142; por. J. R a j m a n, Sredniowieczne patrocinia..., dz. cyt., s. 67.

${ }^{38}$ Zob. KDK 2, nr 533

${ }^{39}$ Zob. LB 2, s. 3.

${ }^{40}$ Zob. Księga dochodów..., dz. cyt., s. 193-194, 127; zob. też: APkM, vol. 45, fasc. A; por. Wizytacje.., dz. cyt., s. 317-318. Por. B. K u mor, Dzieje..., dz. cyt., s. 539, tabela 76 (gdzie autor datuje fundację uposażenia II ministerium na rok 1519).

${ }^{41}$ Zob. E. P i wo w a r c z yk, Dzieje..., dz. cyt., s. 142-143; por. J. R a j m a n, Srednio-

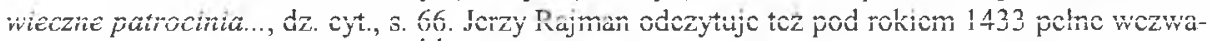
nie ołtarza: Nawiedzenia NPM, ŚŚ. Jana i Pawła Męczenników, Leonarda, Ludwika Króla, Hipolita, Władysława, Pantaleona, Stanisława, Klary, Agnieszki, Apolonii, Łucji, Praksedy i Petroneli. Wydaje się jednak, iż święci ci odnoszą się do wezwania altarii I ministerium, a zatem tylko pośrednio do ottarza Nawiedzenia NPM. Wśród dokumentów dotyczących patrocinium Nawiedzenia NPM Rajman podaje również pod rokiem 1519 informację o ołtarzu Nawiedzenia NPM w kaplicy Waltka. Tam zaś znajdował się ołtarz Męki Pańskiej, a kaplica wystawiona została tylko na wzór kaplicy poświęconej Zwiastowaniu NPM fundacji Teodoryka Weinricha. Natomiast Bolesław Kumor (w: Dzieje...) ołtarza Zwiastowania NPM nie wymienia, w jego zaś miejsce wzmiankuje - zgodnie z wizytacją z roku 1711 - późniejszy ołtarz Poczęcia NPM.

${ }^{42}$ Zob. ZDKK 2, nr 319, 320, 322.

${ }^{43}$ Zob. LB 2, s. 3. 
rium $)^{44}$. W dokumencie zaś z roku 1437 zapisano: „Nicolao Petri molendinatoris de Nebirsdorff alias Nebrowicz Wratislauiensis dyocesis altariste altaris s. Anne in ecclesia S. Marie in Cracovia siti" ${ }^{45}$. Według Jana Długosza, patronat nad I ministerium tego ołtarza, altarii ku czci św. Anny, należał do rajców krakowskich, z ich zaś wyboru altarystą był niejaki „Slupensky”; uposażenie altarii czerpano z czynszów z domów krakowskich ${ }^{46}$. W roku 1529 przeniesiono też $\mathrm{z}$ altarii bytomskiej (1530) uposażenie dla altarysty II ministerium przy tym ołtarzu ${ }^{47}$. Funkcję altarysty II ministerium objął Józef z Krakowa, czerpiący z racji funkcji uposażenie ze wsi: Czyżyny, Prandocin i Kacice oraz Polikarcice i Karniowice. Natomiast I ministerium uposażali rajcy krakowscy, altaria zaś znajdowała się pod patronatem przeora klasztoru mogilskiego Erazma; altarystą tego ministerium był wspomniany Józef z Krakowa ${ }^{48}$.

Z kolei, najprawdopodobniej jeszcze w 1. ćwierci XV stulecia sprawiono oltarz Św. Krzyża (S. Crucis), ustawiony przy wschodniej ścianie południowej nawy bocznej ${ }^{49}$. Już bowiem w roku 1439 ksiądz Jan Stolle (z Głogowa na Śląsku), spisując swój pierwszy testament wyraził życzenie, aby ustanowiono z jego funduszu m.in. osobna altarię przy ołtarzu Św. Krzyża ${ }^{50}$. Ottarz ten zatem istniał przed rokiem 1439 i posiadał prawdopodobnie uposażone I ministerium. W późniejszym jednak czasie ksiądz Stolle odwolał testament, a w jego miejsce spisał (1454) no$w^{51}$. Na jego to właśnie mocy uposażono m.in. II ministerium przy oltarzu Św. Krzyża, nad którym patronat powierzono Janowi Swedniczarowi i Mikołajowi Schonbergowi. W związku jednak ze śmiercią nie tylko księdza Stolle, ale i Jana Swedniczara, zatwierdzenie uposażenia II ministerium nieco się odwlekło, a w konsekwencji sporów uposażono go w roku 1460 czynszem z Okocimia i Jasienia ${ }^{52}$.

${ }^{44}$ Zob. J. R a j m a n, Średniowieczne patrocinia.., dz. cyt, s. 62 (J. Rajman jednak wzmiankuje o altarii i kaplicy ŚŚ. Anny i Elżbiety); por. E. P j w o w a r c z y k, Dzieje.., dz. cyt., s. 143.

${ }^{45}$ CA Supl. 1433-1440, nr 177, s. 89.

${ }^{46}$ Zob. LB 2, s. 4. Por. B. K u m o r, Dzieje..., dz. cyt., s. 543, tabela 80 (co prawda autor nie podaje wezwania oltarza, wskazuje niemniej na istnienie przy nim altarii z uposażonym I ministerium, z fundacji jakiegoś mieszczanina).

${ }^{47}$ Zob. APkM, dypl. nr 103(176); por. Wypisy źródlowe do dziejów Wawelu 1530-1533, wyd. B. Przybyszewski, Kraków 1986 (Źródta do dziejów Wawelu, t. 11, cz. 2), nr 475. Por. B. K u m o r, Dzieje..., dz. cyt., s. 543 , tabela 80 i s. 527 , tabela 68 - to samo uposażenie ministerium wzmiankuje bowiem Bolesław Kumor również przy ołtarzu głównym. Tymczasem uposażenie to jeszcze w roku 1529 należało do altarysty ołtarza Św. Anny i dopiero w późniejszym okresie zostało przeniesione do ołtarza głównego.

${ }^{48}$ Zob. Księga dochodów..., dz. cyt., s. 166, 166-167, 470; por. Wizytacje..., dz. cyt., s. $327-330$.

${ }^{49}$ Zob. E. P i w ow a r c zy k, Dzieje..., dz. cyt., s. 143; por. J. R a j m a n, Sredniowieczne patrocinia..., dz. cyt., s. 64. Zob. też: B. Ku mor, Dzieje.., dz. cyt., s. 530. Bolesław Kumor upatruje jednak fundatora ołtarza Św. Krzyża w osobie Jana Stolle, który uposażył tylko II ministerium przy istniejacym wcześniej ołtarzu.

${ }^{50}$ Zob. CA I, nr 344.

${ }^{51}$ Zob. KDK 2, nr 439. Por. J. R a j m a n, Średniowieczne patrocinia..., dz. cyt., s. 64. Według Jerzego Rajmana ołtarz ten był w roku 1455 na nowo ufundowany i erygowany. W roku zaś 1471 miał zostać (po raz drugi?) ufundowany przez Mikołaja Schonberga, notariusza królowej i miejskiego.

${ }^{52}$ Zob. KDK 2, nr 452. Por. B. K u m o r, Dzieje..., dz. cyt., s. 531, tabela 72 (tam też Bolesław Kumor przypisuje fundacji Jana Stolle dwa ministeria. Drugie ze wskazanych przynależało jednak do ołtarza Św. Szymona i Judy. 
Istnienie przy ołtarzu Św. Krzyża dwóch ministeriów potwierdził również Jan Długosz w Liber beneficiorum, gdzie odnotował, iż pierwszego altarystę wybierali rajcy krakowscy, którzy też uposażali altarię na czynszach z domów krakowskich; $\mathrm{z}$ ich zapewne wyboru altarystą był wówczas Jan Czeyskyendorff z Krakowa. Na drugą altarię, uposażoną na wsi Piasek, prezentowali altarystę fundator oraz notariusz miasta ze swoimi sukcesorami; $\mathrm{z}$ ich zapewne wyboru altarię posiadał (od 1460) niejaki Bernard ${ }^{53}$. Koleje uposażenie altaryści ołtarza otrzymali z zapisu Jana Berga w roku 1480, natomiast już w roku 1488 Barbara Knollówna, jako jedyna spadkobierczyni swojego ojca Mikołaja Knolla, ofiarowała patronat nad II ministerium ołtarza Św. Krzyża klasztorowi bernardynek św. Agnieszki ${ }^{54}$. Sześć lat później patronat nad I ministerium tego oltarza nadal sprawowali rajcy krakowscy, którzy prowadzili sprawę przeciwko Tomaszowi Potrzebie i jego żonie Barbarze o zaległości w placeniu uposażenia dla altarysty, zabezpieczonego na czynszu z domu przy ulicy Szewskiej; altarystą był wówczas Jan Galhart, proboszcz z Szebni ${ }^{55}$. Natomiast już w początkach następnego stulecia, w roku 1529, I ministerium ołtarza Św. Krzyża uposażały czynsze z domów przy ulicach: Mikołajskiej, św. Szczepana, Szewskiej oraz z Rybitw, Czarnej Wsi i ogrodów Slakerowej; altarystą był wówczas Stanisław Słupski. Natomiast altarystą II ministerium był Stanisław z Krakowa czerpiący z racji funkcji uposażenie ze wsi Jasień ${ }^{56}$.

Zapewne mniej więcej w tym samym czasie (przed 1440) co oltarz Św. Krzyża, ufundowano ołtarz dedykowany Św. Agnieszcze (S. Agnetis), który ustawiono przy ścianie północnej bocznej nawy, między wejściami do kruchty a kaplicy Bożego Ciała ${ }^{54}$. W roku 1440 odnotowano już w źródłach altarystę tego ołtarza, którym był Maciej Peyzer; trzy lata później (1443) na stanowisku tym zapisano w dokumentach Klemensa z Będzina ${ }^{58}$. W roku 1444 zanotowano też fundację uposażenia altarii na mocy testamentu Piotra Hirsberga (Hersberga, Herschberka), który patronat nad ołtarzem darował Plotrowi Oleatorowi, egzekutorow1 swojego testamentu $^{59}$. Wkrótce jednak patronat nad ołtarzem Św. Agnieszki przeszedł na Mikołaja Cromera i jego potomków, jako że takowych patronów zapisał Jan Długosz w Liber beneficiorum ${ }^{60}$. Zapewne z ich właśnie prezenty altarystą był (1468) Mikołaj Skoczek, po którym najprawdopodobniej stanowisko to objal (1481)

\footnotetext{
${ }^{53}$ Zob. LB 2, s. 3.

${ }^{54}$ Zob. CA Supl.Kr, s. 79

${ }^{55}$ Zob. CA 1, nr 1172. Jana Galharta zastępował Jakub Wallendorf.

${ }^{56}$ Zob. Księga dochodów..., dz. cyt., s. 119, 156; zob. też: APkM, vol. 45, fasc. A; por. Wizytacje.., dz. cyt., s. 305-308.

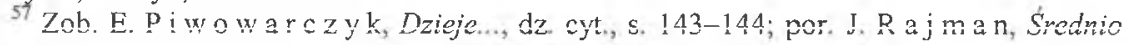
wieczne patrocinia.., dz. cyt., s. 61 (gdzie autor wymienia jako pierwsze źródło odnoszace się do owego ołtarza dokument z roku 1444). Zob. też: B. K u m o r, Dzieje..., dz. cyt., s. 554. Bolesław Kumor wskazuje również - opierając siẹ na bulli papieskiej z 21 IV 1400 roku - na fundację ołtarza przed rokiem 1400 . W dalszej jednak części opracowania (tamże, s. 560) sam nawiązuje do owego dokumentu podając inną datę dzienna jego wystawienia (27 IV) i wzmiankuje tym razem ołtarz ŚŚ. Trzech Króli.

${ }^{58}$ Zob. M. Fr i edberg, Zalożenie..., dz. cyt., s. 28, przyp. 1; por. J. R a j ma n, Średniowieczne patrocinia..., dz. cyt., s. 61.

${ }^{59}$ Zob. KDK 2, nr 544. Por. B. K u m o r, Dzieje..., dz. cyt., s. 536 (gdzie autor łączy altarię z ołtarzem Męki Pańskiej w kaplicy Michała Czirli).

${ }^{60}$ Zob. LB 2, s. 5.
} 
Marcin Ryncza ${ }^{61}$. Formalne jednak erygowanie I ministerium altarii ku czci św. Elżbiety nastapiło dopiero w roku $1483^{62}$, ponownego zaś uposażenia dokonano zapisem Mikołaja Kozy z roku $1493^{63}$. Il ministerium przy tym ołtarzu, altarii ku czci śś. Agnieszki, Perpetuy i Felicity, Piotra z Werony, a także Jana i Pawła Męczenników, ufundowane zostało na mocy zapisu testamentowego (1493) Mikołaja Jedwata, mieszczanina krakowskiego, przez wykonawców jego testamentu Macieja Bednarza z Myślenic i Stanisława Jedwata z Krakowa. Erygowano je w roku 1494, altaria zaś uposażona została czynszen rocznym 12 grzywien za-

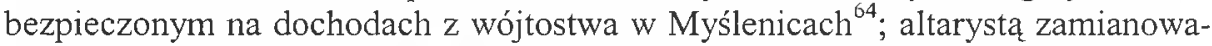
no (prawdopodobnie już w roku 1494, jako że wówczas odnajdujemy o nim wzmianke) Piotra z Brzeska ${ }^{65}$. Natomiast jeszcze w roku 1504 uposażono ponownie, z zapisu Jana Wielogłowskiego, I ministerium przy ołtarzu Św. Agnieszki ${ }^{66}$. W roku 1529 altaria ta uposażona była na dobrach klasztoru Św. Andrzeja, natomiast altarystą II ministerium był w owym czasie Bartłomiej Gątkowski, czerpiący $\mathrm{z}$ racji funkcji uposażenie $\mathrm{z}$ Myślenic ${ }^{67}$.

Kolejny ołtarz do kościoła, ku czci Wniebowzięcia NPM (Assumptionis S. Mariae Virginis Gloriose), sprawiono przed rokiem 1443 z zapisu niegdysiejszego krawca królowej i rajcy krakowskiego (1441-1442) Piotra z Pyzdr ${ }^{68}$; ustawiono go najprawdopodobniej przy pierwszym filarze nawy południowej (licząc od prezbiterium) ${ }^{69}$. Ołtarz ten erygowany został w roku 1443 i wówczas też uposażono przy nim, z zapisu wspomnianego Piotra, czynszem rocznym 12 grzywien zabezpieczonym na żupach wielickich, I ministerium altarii ku czci Wniebowzięcia NPM i ŚŚ. Hieronima, Piotra i Pawła, Dziesięciu Tysięcy Męczenników, Katarzyny, Barbary i Petroneli ${ }^{70}$. Uposażenie to istniało równiez $w$ połowie $\mathrm{XV}$ wieku, kiedy to altarysta I ministerium czerpał uposażenie z racji funkcji z żup i cła z ro-

${ }^{61}$ Zob. M. Fri ed be r g, Zatożenie..., dz. cyt., s. 28, przyp. 1.

${ }^{62}$ Zob. APkM, vol. 45, fasc. A. Por. B. Ku mo r, Dzieje..., dz. cyt., s. 554 . Wprawdzie Bolesław Kumor nie podaje ani daty, ani fundatora owego uposażenia, określa go jednak na 8 grzywien rocznego czynszu. W dalszej też części opracowania nazywa to ministerium ołtarzem Św. Elżbiety.

${ }^{63}$ Zob. CA 1, nr 1131.

${ }^{64}$ Zob. APkM, dypl. nr 62(119), 63(121), 66(124); por. tamże, vol. 45, fasc. A. Por. B. K u m or, Dzieje..., dz. cyt., s. 554. Tam teź Bolesław Kumor, pisząc o II ministerium, podał jakby to było to samo - erygowanie ołtarza na rok 1533. Jak się jednak zdaje, miał na myśli erygowanie ministerium, choć i ta data jest błędna.

${ }^{65}$ Zob. M. Fri ed be r g, Zatożenie..., dz. cyt., s. 28, przyp. 1.

${ }^{66}$ Zob. APkM, vol. 45, fasc. A. Zob. też: J. R a j m a n, Sredniowieczne patrocinia..., dz. cyt., s. 61 .

${ }^{67}$ Zob. Ksiega dochodów..., dz. cyt., s. 180, 346; por. Wizytacje..., dz. cyt., s. 353-354.

68 Zob. ZDKK 2, nr 430. Ów Piotr zapisał też w swoim testamencie na rzecz kościoła Panny Marii 20 grzywien - zob. APkM, dypl. nr 30(59).

${ }^{69}$ Zob. E. P j w o w a r c z y k, Dzieje..., dz. cyt., s. 144; por. J. R a j m a n, Średniowieczne patrocinia..., dz. cyt., s. 68. Jerzy Rajman odczytal tez pełne wezwanie ołtarza: Wniebowzięcia NPM, ŚŚ. Hieronima, Piotra, Pawła, 10 Tysięcy Męczenników, Katarzyny, Barbary i Petroneli. Wezwania tych świętych odnoszą sję jednak do altarii I ministerium, a tym samym tylko pośrednio do wezwania ołtarza ku czci Wniebowzięcia NPM. Natomiast Bolesław Kumor (w: Dzieje...) ołtarza Wniebowzięcia NPM nie wymienia, podając tylko uposażenie przez Piotra z Pyzdr II ministerium altarij Wniebowzięcia NPM przy ołtarzu Sw. Aleksego - zob. B. K u mo r, Dzieje..., dz. cyt., s. 542, tabela 79.

${ }^{70}$ Zob. APkM, dypl. nr 31(60) [druk: ZDKK 2, nr 443]. 
gatki; patronat nad altarią sprawowali wówczas wspólnicy Jakuba Szwinczara $z_{\text {Krakowa }}{ }^{71}$. W późniejszym jednak czasie, w początkach XVI stulecia (ok. 1508) uposażenie to przeniesiono na altarię II ministerium ołtarza w kaplicy Św. Marka (obecnie Św. Wawrzyńca) ${ }^{72}$, stąd też nie odnotowano go w roku 1529.

Natomiast jeszcze przed rokiem 1446 uposażono II ministerium przy - istniejącym już około roku $1433^{73}$ - ołtarzu Zwiastowania NPM (Annuntiationis B.M.V.), ustawionym przy tęczy po stronie północnej nawy bocznej ${ }^{74}$. Na mocy zapisu testamentowego Jana Plesznera z roku 1446 uposażone ono zostało czynszem rocznym 8 grzywien czeskich zabezpieczonym na wójtostwie zatorskim; zapis Plesznera na II ministerium altarii ku czci Wniebowzięcia NPM zatwierdził wikariusz generalny krakowski Jan ze Lgoty (Jan Elgot) ${ }^{75}$. Również w czasach Jana Długosza ołtarz ten miał dwa ministeria. Altarystą I ministerium, uposażonego na Uszycach, był Mikołaj Langmiter, który również sprawował patronat nad altarią. Natomiast prawo prezenty na II ministerium przysługiwało Marcinowi Byeczsky wraz z siostrą $i$ on też był altarysta, czerpiąc uposażenie $z$ racji funkcji z dóbr Zator $^{76}$. I ministerium ponownie uposażono jeszcze $\mathrm{w}$ roku 1471, $\mathrm{z}$ zapisu braci Watróbków: Stanisława (kasztelana sandeckiego) i Jana (kanonika krakowskiego), którzy złożyli na ten cel obligację opiewającą na 400 złotych węgierskich, poniesioną z dóbr Luborzyce i zabezpieczoną na wszystkich dochodach miasta Ujścia ${ }^{77}$. Natomiast uposażenie II ministerium przy tym ołtarzu, altarii ku czci śś. Jana Chrzciciela i Barbary, zostało przeniesione z kaplicy Św. Barbary, gdzie było legowane zapisem testamentowym Hanka Bartha $\mathrm{z}$ roku 1402; uposażone było wówczas na Garbarach i Nowej Wsi ${ }^{78}$. W roku zaś 1482, z zapisu Pawła Nayburgera (Neubirgera), uposażono również III ministerium przy ołtarzu Zwiastowania $\mathrm{NPM}^{79}$. Wkrótce jednak ministeria te (II i III) zanikty, jako że w Liber retaxationum z roku 1529 odnotowano tylko uposażenie I ministerium, którego altarysta Jan z Krakowa - czerpał uposażenie z dóbr Ujścia ${ }^{80}$.

Przed rokiem 1446 sprawiono też nowy ołtarz do kaplicy międzywieżowej Bractwa Wniebowzięcia NPM ${ }^{81}$. W tym bowiem roku niejaki Bartłomiej Prusko-

${ }^{71}$ Zob. LB 2, s. 4.

${ }^{72}$ Zob. APkM, dypl. nr 31(60), zapis na dokumencie in dorso z XVII wieku.

${ }^{73}$ Zob. J. R a j m a n, Średniowieczne patrocinia..., dz. cyt., s. 68.

${ }^{74}$ Zob. E. P i w o w a r c z y k, Dzieje..., dz. cyt., s. 144-145.

${ }^{75}$ Zob. APkM, dypl. nr 33(64) [druk: ZDKK 2, nr 490].

${ }^{76}$ Zob. LB 2, s. 5. Por. B. K u mor, Dzieje.., dz. cyt., s. 558, tabela 93 (autor jednak upatruje fundatorów I ministerium w osobach Stanisława i Benigny Reynierów, zapis zaś uposażenia wskazuje na przed rokiem 1470).

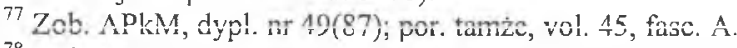

${ }^{78}$ Zob. tamze, vol. 45, fasc. A; por. Wizytacje..., s. 361. Por. B. Ku mor, Dzieje..., dz. cyt., s. 558, tabela 93 (gdzie autor wskazuje na fundatora II ministerium w osobie Hanka Bartulfa.

${ }^{79}$ Zob. APkM, vol. 45, fasc. A. Por. B. K u mo r, Dzieje..., dz. cyt., s. 559, tabela 93 (autor wymienia jednak nazwisko fundatora $w$ brzmieniu: Nauberger, nie podając daty fundacji).

${ }^{80}$ Zob. Księga dochodów..., s. 145; por. Wizytacje..., dz. cyt., s. 360-363.

${ }^{81}$ Zob. J. R aj ma n, Średniowieczne patrocinia..., dz. cyt., s. 68. Jerzy Rajman odwołuje się też do dokumentu z roku 1440, w którym wzmiankowany jest ów ołtarz ku czci: Wniebowzięcia, Niepokalanego Poczęcia, Narodzenia, Nawiedzenia, Oczyszczenia, Zwiastowania NPM, św. Jana Chrzciciela, 11 Tysięcy Świętych Dziewic i św. Marii Magdaleny. Tak poszerzone wezwanie odnosi się jednak do wezwania altarii I ministerium przy ołtarzu Wniebowzięcia NPM, a zatem tylko pośrednio do patrocinium oltarza. 
nis zrzekł się prawa patronatu nad altaria przy tym ołtarzu na rzecz owego Bractwa $^{82}$. Istnienie ołtarza Wniebowzięcia NPM potwierdził również Jan Długosz w Liber beneficiorum, który co prawda wezwanie zapisał w sposób nieczytelny, niemniej zanotował, iż znajdował się on ,, in lectorio seu in choro fratrum”, a prawo patronatu należało do Bractwa Wniebowzięcia NPM. Według tego też historyka I ministerium przy oltarzu Wniebowzięcia NPM uposażały czynsze z domów krakowskich, altarystą zaś był „doctor Clemens"83. Patronat Bractwa utrzymał się jeszcze pod koniec XV wieku, w roku zaś 1501 starsi zamianowali altarystą Jana Salomona, scholastyka gnieźnieńskiego i kanonika krakowskiego ${ }^{84}$. W roku 1518 odnotowano też w dokumentach zapis dla Jana Salomona, altarysty ołtarza Wniebowzięcia NPM w kaplicy „na chórze”, z konsekwencją przynależności do każdorazowego altarysty tego ołtarza - a zatem uposażenie I ministerium, opiewające na 16 grzywien rocznego czynszu zabezpieczonego na dobrach królewskich Lelów i Suliborowice w ziemi sieradzkiej ${ }^{85}$. Również $w$ początkach następnego stulecia (1529) uposażenie tego ministerium stanowiły dobra Lelów i przynależne do niego wsie; altarystą był wówczas Erazm (z Krakowa, doktor dekretów) ${ }^{86}$ :

Nie potrafimy natomiast bliżej określić czasu sprawienia ołtarza Św. Leonarda (S. Leonardi), ustawionego najprawdopodobniej przy pierwszym filarze (licząc od prezbiterium) północnej nawy bocznej ${ }^{87}$. Wymieniony przez Jana Długosza W Liber beneficiorum, istniał zapewne około roku 1460, będąc ufundowanym przez Piotra Graszera ${ }^{88}$. Pełne wezwanie tego ołtarza brzmiało: ŚŚ. Piotra i Pawła a także Leonarda (S. Petri et Pauli nec non Leonardi), aczkolwiek nazywany był także ołtarzem ŚŚ. Piotra w okowach i Leonarda Wyznawcy (tituli Sanctorum Petri ad Vincula et Leonhardi Confessoris) ${ }^{89}$. W czasach powstawania Liber beneficiorum prawo patronatu do tego ołtarza przysługiwało niejakiej Wynkowej, altaria zaś uposażona była na łaźni wielickiej ${ }^{90}$. Z kolei w roku 1468 legatu na tenże oftarz dokonal ksiądz Paweł Wagier z Krakowa, który to zapis powiększyli w roku 1481 Zaifred Bethman i jego żona Urszula (siostra Pawła Wagiera) przeznaczając na uposażenie czynsz z jatki rzeźniczej na Kleparzul'. Być może jednak, iż uposażenie to wkrótce zanikło, jako że takowego nie odnotowano w Liber retaxationum z roku 1529.

${ }^{82}$ Zob. APkM, vol. 47 , fasc. 3 , nr 4 B.

${ }^{83}$ Zob. LB 2, s. 4.

${ }^{84}$ Zob. APkM, dypl. nr 77(136). Por. B. K u m o r, Dzieje..., dz. cyt., s. 563 (tam też autor wskazuje na fundację II ministerium w roku 1493, uposażonego czynszem 13 grzywien, przez Bartłomieja Russka).

${ }^{85}$ Zob. APkM, dypl. nr 91(156), 92 (157); por. tamże, vol. 45, fasc. A.

${ }^{86}$ Zob. Księga dochodów..., dz. cyt., s. 146.

${ }^{87}$ Zob. E. P i w ow a r c z y k, Dzieje..., dz. cyt., s. 145; por. J. R a j m a n, Średniowieczne patrocinia..., dz. cyt., s. 65. Natomiast Bolesław Kumor (w: Dzieje...) tego ołtarza nie wymienia.

${ }^{88}$ Zob. LB 2, s. 4.

${ }^{89}$ Zob. Wypisy źródtowe do dziejów Wawelu 1526-1529, wyd. B. Przybyszewski, Kraków 1984 (Źródła do dziejów Wawelu, t. 11, cz. 1), nr 71.

${ }^{90}$ Zob. LB 2, s. 4.

${ }^{91}$ Zob. APkM, vol. 45, fasc. A. 


\section{XV-WIECZNE OŁTARZE KAPLICOWE}

Nieco inną możliwość pobożnościowo-wotywnych fundacji ołtarzy do kościoła Panny Marii uzyskali mieszczanie krakowscy w 2. ćwierci XV stulecia, w związku z dostawieniem do korpusu nawowego (przed 1435-1446) zewnętrznych kaplic. Co prawda nie do wszystkich fundacji tych kaplicowych ołtarzy zachowały się odnośne dokumenty, niemniej możemy mniemać, iż sprawianie ich następowało mniej więcej równocześnie $\mathrm{z}$ ukończeniem prac budowlanych, niejednokrotnie na podstawie tego samego zapisu. Wydaje się także bardzo prawdopodobnym, iż ołtarze te otrzymywały pierwotnie takie wezwania, pod jakimi znane były wówczas kaplice. Dlatego też, uwzględniając czas wznoszenia kaplic w 2. ćwierci XV stulecia, można wskazać kolejnych dziesięć ołtarzy ufundowanych do krakowskiej fary w latach około 1435-1446.

Jako pierwszy sprawiono zapewne jeszcze około roku 1435 ołtarz kaplicowy MB Śnieżnej (Beatissimae Mariae Virginis ad Nives) - - w kaplicy fundacji Jadwigi z Kunczów Sebastianowej) ${ }^{92}$. Według Jana Dlugosza, patronem tego oltarza był Sebastian, mieszczanin krakowski, altarysta zaś czerpał uposażenie z czynszów domów krakowskich (m.in. z domu Stanisława Kotlarza ${ }^{93}$ ) i Stradomia. Na stanowisko altarysty I ministerium altarii ku czci MB Śnieżnej mianowany był jeden z wikarych seniorów kościoła Panny Marii; w owym czasie altarystą był Jan z Koprzywnicy ${ }^{94}$. II ministerium przy tym ołtarzu, altarii ku czci Ofiarowania NPM i św. Jana Chrzciciela oraz wszystkich Zastępów Niebieskich, ufundowane przez Stanisława z Piotrkowa, podzakrystiana kościoła Panny Marii, erygowano w roku 1494; uposażenie stanowiło 20 złotych węgierskich z jatek rzeźniczych krakowskich oraz 4 złote węgierskie $z$ żup wielickich ${ }^{95}$. Nieco później też (1502) uposażono ponownie I ministerium altarii ku czci MB Śnieżnej, II zaś ministerium przy tym ołtarzu powiększone zostało zapisem z roku $1514^{96}$. Natomiast jeszcze przed rokiem 1529 uposażono także III ministerium przy ołtarzu MB Śnieżnej, jako że takowe odnotowano w Liber retaxationum $\mathrm{z}$ tego roku. III ministerium, którego altarystą był Albert z Łukowa, uposażone wówczas było na domach przy ul. św. Floriana, łaźni zwanej Rogacką oraz Stradomiu. Altarysta II ministerium, którym był $w$ owym czasie Leonard z Krosna, czerpał uposażenie $z$ racji funkcji z żup wielickich; I zaś ministerium, którego altarystą był Marcin z Łańcuta, uposażone było na wsiach: Brzezie, Dąbrowa i Szarów ${ }^{97}$.

${ }^{92}$ Zob. E. P i w o w a r c zy k, Dzieje..., dz. cyt., s. 146; por. J. R a j m a n, Średniowieczne patrocinia..., dz. cyt., s. 65 (autor podaje jednak jako pierwsze źródło odnoszące się do tego ołtarza dokument $\mathrm{z}$ roku 1483).

${ }^{93}$ Zót. CA Süpi.Ki, s. 151-152.

${ }^{94}$ Zob. LB 2, s. 4. Por. B. Ku mor, Dzieje..., dz. cyt., s. 539, tabela 77. Według Bolesława Kumora fundatorem uposażenia I ministerium w roku 1467 był niejaki Volgelvend i od niego tez kaplica ta zwać się miała Volgelvendów (chodzi oczywiście o Fogelwederów). Tymczasem kaplica ta pierwotnie należała do Kunczów, a Fogelwederowie, konkretnie zaś Stanisław Fogelweder, przejęli ją dopiero w roku 1588.

${ }^{95}$ Zob. APkM, dypl. 67(125); por. tamże, vol. 45, fasc. A. Por. B. K u mor, Dzieje ..., dz. cyt., s. 539, tabela 77 (gdzie autor określił altarię jako Oczyszczenia NPM i św. Jana Chrzciciela nie podając roku fundacji uposażenia II ministerium).

${ }^{96}$ Zob. APkM, vol. 45, fasc. A.

${ }^{97}$ Zob. Ksiega dochodów..., dz. cyt., s. 102, 242-243, 344; por. Wizytacje..., dz. cyt., s. 318-321. Por. B. K u m o r, Dzieje..., dz. cyt., s. 539, tabela 77 (tam też autor wskazał na uposa- 
Mniej więcej w tym samym czasie (około roku - bądź wkrótce po - 1435) ufundowano ołtarz kaplicowy Przemienienia Pańskiego (Transfigurationis Domini) - w kaplicy fundacji Jana Dolnicza) ${ }^{98}$. Około połowy XV wieku prawo prezenty na altarię przy tym ołtarzu posiadali sukcesorzy Sebenwirta i Solwecz Sylwestrowej oraz rajcy krakowscy, altaria zaś, ku czci św. Jana Chrzciciela, uposażana była przez miasto ${ }^{99}$. Kolejne, II ministerium przy tymże ołtarzu, altarii ku czci Przemienienia Pańskiego, śś. Hieronima, Bernarda, Chryzostoma, Leonarda Wyznawcy, erygowano w roku 1490, na mocy zapisu testamentowego Mikołaja Dobschicza, kanonika kościoła kolegiackiego w Nowym Sączu ${ }^{100}$. W roku 1529 było ono jedynym istniejącym (ołtarz odnotowano pod wezwaniem altarii: św. Hieronima), jego zaś altarysta, Jan z Nyssy, czerpał z racji funkcji uposażenie ze wsi Bełze oraz dwóch jatek rzeźniczych w Krakowie ${ }^{101}$.

Około roku - bądź wkrótce po - 1435 sprawiono też oltarz poświęcony Męce Pańskiej (Passionis Domini) - w kaplicy fundacji Michała Czirli ${ }^{102}$. W roku 1435 rajcy krakowscy potwierdzili bowiem darowiznę czynszu, dokonaną zapisem testamentowym Michała Czirli (1435), pobieraną z cła krakowskiego, na rzecz kaplicy i ołtarza, przy którym I ministerium zostało osobno uposażone rocznym czynszem 5 grzywien ${ }^{103}$. Jednak już w czasach spisywania Liber beneficiorum ministerium to zanikło, jako że - jak odnotował Jan Długosz - ołtarz nie miał w owym czasie altarysty, a altaria nie posiadała uposażenia ${ }^{104}$; ponowne uposażenie ministerium nastapiło w roku $1491^{105}$. W roku 1519 zrzekl się też prawa do patronatu nad tym ołtarzem - zwanym wówczas 11.000 Męczenników - Stanisław Karniowski, mieszczanin krakowski, oddając go rajcy krakowskiemu Janowi Kislingowi i jego potomkom ${ }^{106}$. Z zapisu tego ostatniego erygowano też, na krótko przed rokiem 1529, II ministerium przy ołtarzu Męki Pańskiej, altarii ku czci Miłosierdzia NPM, śś. Jana, Stanisława, Erazma Męczennika ${ }^{107}$. Pod tym też wezwa-

żenie III ministerium altarii ku czei Ofiarowania NPM przez niejakiego Kunoczowicza jeszcze przed rokiem 1470 ).

${ }^{98}$ Zob. E. P i wo w a r c z y k, Dzieje..., dz. cyt., s. 146-147; por. J. R a j ma n, Średniowieczne patrocinia..., dz. cyt., s. 64 (gdzie jednak autor wymienia ołtarz pod wezwaniem altarii: św. Jana Chrzciciela). Zob. też: B. Kumor, Dzieje..., s. 538. Bolesław Kumor podaje też, iż kaplica uposażona była przez rodzinę Wottkonów (chodzi oczywiście o Waltków) i w 1491 roku znano ja jako ŚŚ. Aniołów Stóżów. To zaś z pewnością nie odnosi się do kaplicy Przemienienia Pańskiego, podobnie jak podane przez Kumora ministeria przy ołtarzu kaplicowym.

${ }^{99}$ Zob. LB 2, s. 3-4. Por. J. R a j m a n, Średniowieczne patrocinia..., dz. cyt., s. 64 (gdzie jednak autor wymienia ołtarz pod wezwaniem św. Jana Chrzciciela).

${ }^{100}$ Zob. APkM, dypl. nr 59(107); por. tamże, vol. 45, fasc. A.

101 Zob. Księga dochodów..., dz. cyt., s. 329; por. Wizytacje..., dz. cyt., s. 315-317.

${ }^{102}$ Zob. E. P i w o w a r c zyk, Dzieje..., dz. cyt., s. 147; por. J. R a j m a n, Średniowieczne patrocinia..., dz. cyt., s. 65. Zob. też: B. K u m o r, Dzieje.., dz. cyt., s. 536. Bolesław Kumor określa jednak kaplicę jako Wottkonów, tymczasem chodzi o Waltków (Kislingów), którzy uposażyli ją w roku 1491.

${ }_{103}$ Zob. ZDKK 2, nr 342.

${ }^{104}$ Zob. LB 2, s. 3.

${ }^{105}$ Zob. W. G ą s i or ow s k i, Kościót..., dz. cyt., s. 17.

${ }^{106}$ Zob. APkM, dypl. nr 94(161).

${ }^{107}$ Zob. CA 2, nr 224, przyp. 2. Por. B. Ku mor, Dzieje..., dz. cyt., s. 538, tabela 75. Autor jednak - jak się zdaje, ponieważ nie podaje imienia fundatora, a jedynie nazwisko - błędnie łączy uposażenie tego ministetrium z oltarzem Przemienienia Pańskiego w kaplicy fundacji Jana Dolnicza. 
niem - Miłosierdzia NPM (Compassionos B.M.V.) - odnotowano w Liber retaxationum z roku 1529 ołtarz i uposażenie ministerium czerpane z Bronowic, którego altarystą był ,de Fraystath" (Marcin z Wschowy?) ${ }^{108}$.

Również w roku 1435 ufundowano oltarz Zwiastowania NPM (Annuntiationis B.M.V.), do kaplicy południowej - fundacji ks. Teodoryka Weinricha ${ }^{109}$. Posiadał on uposażenie na wsi Pysdry, nadane na mocy testamentu Teodoryka Weinricha $\mathrm{z}$ roku 1449 , patronat zaś nad nim fundator przekazał Stanisławowi Polakowi, swojennu przyjacielowi ${ }^{110}$. Również w czasach Jana Długosza patronat nad I ministerium przy tym ołtarzu, altarii ku czci Zwiastowania NPM i św. Jana Chrzciciela, sprawowal Stanisław Polak (bakałarz) i Hieronim (Niemiec z Krakowa); ministerium to, którego altarystą był Mikołaj z Opatowa, uposażone było przez rajców i zabezpieczone na wsi Pysdry ${ }^{111}$. Wkrótce też, w roku 1462, I ministerium ponownie uposażyła Barbara, księżna raciborska ${ }^{112}$. Zdaje się jednak, iż w niedługim czasie owo uposażenie zanikło, a ponowne ufundowano dopiero w roku 1485 z zapisu Mikołaja Stadnickiego, altarysty przy tym ołtarzu; wtedy też zapewne nadano wezwanie altarii ku czci św. Augustyna ${ }^{1 / 3}$, na stanowisko zaś altarysty zamianowano Jana $\mathrm{z}$ Szebni ${ }^{114}$. Według zapisu z roku $1529 \mathrm{w}$ Liber retaxationum, ołtarz Zwiastowania NPM (który odnotowano pod wezwaniem altarii: św. Augustyna) posiadał ministerium uposażone na wsi Niedźwiedź; altarystą był w owym czasie Mikołaj Kraus ${ }^{115}$.

Kolejne z ołtarzy sprawiono do północnych kaplic zewnętrznych kościola Panny Marii. Pierwszym z nich byl zapewne ufundowany po 1439 a przed rokiem 1441, przez Małgorzatę, siostrę żony Szwarca (Szworca), wdowę po Mikołaju Slepkogilu, oltarz Bożego Ciała (Corporis Domini nostri Jesu Christi) ${ }^{116}$ - w kaplicy fundacji Jerzego Szwarca ${ }^{117}$. Już bowiem w roku 1441 papież Feliks V wydał dokument, na mocy którego nadano kaplicy Szwarca odpusty i zezwolono na odbywanie 3 razy w roku procesji z Najświętszym Sakramentem rozpoczynającej się właśnie od ołtarza Bożego Ciała w kaplicy Szwarca ${ }^{18}$. Rok później nadanie

${ }^{108}$ Zob. Ksiega dochodów..., dz. cyt., s. 132; por. Wizytacje.., dz. cyt., s. 312-315.

${ }^{109}$ Zob. E. P i w o w a r c zy k, Dzieje..., dz. cyt., s. 146; por. J. R a j m a n, Średniowieczne patrocinia.., dz. cyt., s. 68. Jerzy Rajman wzmiankuje też przy patrocinium św. Jana Chrzciciela wezwanie ołtarza, ufundowanego przez Teodora Weinricha: Wszechmogacego Boga, $\mathrm{N}$. Panny Marii, Aniołów, Św. Jana Chrzciciela i innych świętych - zob. tamże, s. 64.

${ }^{110}$ Zob. KDK 2, nr 432.

${ }^{111}$ Zob. LB 2, s. 3.

${ }^{112}$ Zob. KDK 2, nr 455. Por. B. K u mo r, Dzieje..., dz. cyt., s. 536. Bolesław Kumor jednak łączy błędnie uposażenie altarii przez księżnę raciborską Barbarę z altarią przy ołtarzu Męki

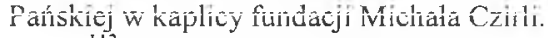

${ }^{113}$ Zob. APkM, vol. 45, fasc. A.

${ }^{114}$ Zob. KDK 2, nr 476.

115 Zob. Ksiega dochodów.., dz. cyt., s. 55; por. Wizytacje.., dz. cyt., s. 308-310.

116 Zob. CA 1, nr 341.

${ }^{117}$ Zob. E. P i w o w a r c z y k, Dzieje..., dz. cyt., s. 147; por. J. R a j m a n, Średniowieczne patrocinia..., dz. cyt., s. 63. Natomiast według Bolesława Kumora kaplica ta wspomniana jest już w roku 1438 w suplice króla Władysława Jagiełły do papieża Marcina V-zob. B. K u m o r, Dzieje..., dz. cyt., s. 555. Niestety, autor ten nie powołuje się na żadne źródło, stąd też nie wiadomo, o jaką suplikę chodzi i czy faktycznie znajduje się tam jakowaś wzmianka na temat owej kaplicy.

${ }^{118}$ Zob. KDK 2, nr 423; por. ZDKK 2, nr 437. 
papieskie potwierdził biskup krakowski Zbigniew Oleśnicki ${ }^{119}$, kolejny zaś akt nadający odpusty wystawił w tym też jeszcze roku (1442) legat rzymski kardynał Julian $^{120}$. Według zapisu Jana Dhugosza w Liber beneficiorum, prawo prezenty na I ministerium (w kaplicy nazwanej przez niego: Narodzenia NPM) należało do Thocholowskiej z siostrą oraz rajców krakowskich; altaria uposażona była na wsi Bronowice ${ }^{121}$. Zapewne z prezenty patronów ołtarza w roku 1491 altarystą I ministerium zostal Mikołaj syn Krystyna z Lublina ${ }^{122}$. Natomiast II ministerium oltarza Bożego Ciała, altarii ku czci św. Erazma, ufundowane zostało w roku 1479 przez Erazma Kreydlara i jego siostrę Barbarę Waltek; erygowano je siedem lat później $(1486)^{123}$. Prawdopodobnie to właśnie $\mathrm{z}$ ich wyboru w roku 1491 altarystą II ministerium został Jan Kreydlar ${ }^{124}$. W roku zaś 1529 , w Liber retaxationum, odnotowano uposażenie II ministerium, którego altarystą byl wówczas doktor dekretów Bork (Borek Stanisław z Krakowa), czerpiący uposażenie $\mathrm{z}$ racji funkcji z dóbr Bronowice; I ministerium uposażone było na starym cle krakowskim, altarystą zaś był bliżej nieznany doktor dekretów ${ }^{125}$.

Wkrótce też, około roku 1441, ufundowano ołtarz kaplicowy ku czci Św. Trójcy (S. Trinitatis), którego pełne wezwanie brzmiało: Św. Trójcy i Nawiedzenia Błogosławionej i Niepokalanej Marii (Sanctissime Trinitatis et Visitationis Beatissime et Intemerate Virginis Marie) - w kaplicy fundacji Marka Noldenfessera ${ }^{126}$. Około roku 1460 prawo prezenty altarysty na I ministerium tego ołtarza, altarii ku czci św. Trójcy i św. Marka Ewangelisty, posiadał Mikołaj Czeyskyendorff, notariusz krakowski; altarystą był wówczas niejaki magister Jan, czerpiący $\mathrm{z}$ racji funkcji uposażenie $\mathrm{z}$ czynszów $\mathrm{z}$ domów krakowskich ${ }^{127}$. II ministerium altarii ku czci św. Benedykta przy ołtarzu Św. Trójcy i Nawiedzenia NPM zostało uposazone w roku 1474 z zapisu Pawła Gertlara czynszem zabezpieczonym na wadze większej krakowskiej; jego erygowanie nastapiło w roku 1489, patronat zaś nad nim sprawowała rodzina Gehanów ${ }^{128}$. Wkrótce jednak ono zanikło, a na jego miejsce przeniesiono dla altarysty II ministerium uposażenie z ołtarza Zwiastowania NPM, fundacji Piotra z Pyzdr ${ }^{129}$. Rok później (1519) jednak Jakub Kyellar, pleban w Starym Korczynie, ponownie uposażył II ministerium w kaplicy

${ }^{119}$ Zob. APkM, vol. 1, fasc. 1 [druk: KDK 2, nr 426]; por. ZDKK 2, nr 437.

${ }^{120}$ Zob. KDK 2, nr 427. W tymże też roku (1442) uposażenie I ministerium altarii ku czci św. Erazma, miał ufundować Jerzy Szworc - zob. AKMKr, Acta.., p. 99r; por. B. K u mor, Dzieje..., dz. cyt., s. 555, tabela 92.

${ }^{121}$ Zob. LB 2, s. 5.

${ }^{122}$ Zob. M. F r i e d b e r g, Zatożenie.., dz. cyt., s. 28, przyp. 1.

${ }^{123}$ Zob. APkM, vol. 45, fasc. A; tamże, vol. 60, fasc. 183, nr 3. Por. B. K u mo r, Dzieje..., dz. cyt., s. 555, tabela 92 (gdzie autor datuje fundację uposażenia II ministerium altarii ku czci Wniebowzięcia NPM, św. Hieronima, św. Piotra, przez Barbarę Kredma na rok 1443).

${ }^{124}$ Zob. M. Fr i e d b e r g, Zalożenie..., dz. cyt., s. 28, przyp. 1.

${ }^{125}$ Zob. Księga dochodów..., dz. cyt., s. 227, 270; por. Wizytacje..., dz. cyt., s. 354-356.

${ }^{126}$ Zob. E. P i w o w a r c z y k, Dzieje..., dz. cyt., s. 147; por. J. R a j m a n, Sredniowieczne patrocinia..., dz. cyt., s. 67. Tam również Jerzy Rajman wspomina o kaplicy Św. Trójcy zwanej kaplicą Waltdorffa - to jednak odnosi się do kaplicy Ducha Św., która rzeczywiście w roku 1478 zwana była Św. Trójcy. Natomiast Bolesław Kumor podaje, iż kaplica ta została wybudowana przed rokiem 1470 - zob. B. K u m o r, Dzieje..., dz. cyt., s. 552.

127 Zob. LB 2, s. 5.

${ }^{128}$ Zob. APkM, dypl. nr 56(99), 57(101); por. tamże, vol. 45, fasc. A.

${ }^{129}$ Zob. tamże, dypl. nr 31(60), XVII-wieczny dopisek na dokumencie in dorso. 
Św. Marka przeznaczając na nie 8 grzywien rocznego czynszu zabezpieczonego na żupach wielickich ${ }^{130}$. Wkrótce też (1521) o obsadę tego misterium, po śmierci altarysty Jana z Olkusza, wszczęto spór, rozsądzony przez Mikołaja Bedleńskiego ${ }^{131}$. Natomiast jeszcze przed rokiem 1521 uposażono przy ołtarzu Św. Trójcy III już ministerium altarii ku czci Św. Trójcy i św. Marka, z fundacji Jerzego Tu$\mathrm{rzo}^{132}$. Odnotowano je też w Liber retaxationum z roku 1529 , w której wymieniono jako altarystę Stanisława z Krakowa czerpiącego z racji funkcji uposażenie ze Spytkowic (k. Wadowic) i Bachowic. II ministerium uposażone było na Gierałtowicach, altarystą zaś był Jan ze Skalbimierza. Natomiast altarystą I ministerium był Erazm z Krakowa, czerpiący z racji funkcji uposażenie z żup wielickich i czynszów krakowskich ${ }^{133}$.

Kolejny ołtarz kaplicowy ufundowano około roku $1443 \mathrm{ku}$ czci św. Michała (S. Michaelis) - w kaplicy fundacji Jana Baomgarta ${ }^{134}$. Według zapisu Jana Długosza w Liber beneficiorum, ołtarz ten w owym czasie nie miał właściciela, lecz kuśnierze mieli tam swojego kleryka, którego uposażali ${ }^{135}$. Altaria nie była również uposażona w roku 1529, jako że nie odnotowano takowego w Liber retaxationum $\mathrm{z}$ tegoż roku ${ }^{136}$.

Ostatni z kaplicowych ołtarzy sprawiono w roku 1445 ku czci Wszechmogącego Boga i Narodzenia NPM (Omnipotentis Dei et Nativitatis eius Genitricis Virginis Marie) - w kaplicy fundacji ks. Stefana Leipingera ${ }^{137}$. W tym bowiem roku (1445) rajcy krakowscy zezwolili na zapis na ołtarz rocznego czynszu 18 grzywien zabezpieczonego na domu kuśnierzy, dokonany przez Stefana Leipingera; w tej też sprawie zwrócił się fundator rok później (1446) do biskupa krakowskiego Zbigniewa Oleśnickiego proszaç o zatwierdzenie ${ }^{138}$. Oleśnicki potwierdził zapis I ministerium altarii ku czci Ducha Św. i Narodzenia NPM, Nawrócenia św. Pawła, Łukasza i Wszystkich Świętych jeszcze w roku 1446, transsumując poprzednie dokumenty ${ }^{i 39}$. Natomiast $\mathrm{w}$ czasach spisywania Liber beneficiorum pa-

${ }^{130}$ Zob. tamże, dypl. nr 81(116), 94(160); por. tamże, vol. 45, fasc. A.

${ }^{131}$ Zob. tamże, dypl. nr 95(163, 164), 96(165).

${ }^{132}$ Zob. W. G ąs i o row sk i, Kościól..., s. 44. Zob. też: B. Ku mor, Dzieje..., s. 552, tabela 90. Bolesław Kumor wzmiankuje jednak to uposażenie jako I ministerium, uposażenie zaś III ministerium altarii Św. Trójcy i św. Marcina, datuje na rok 1522.

${ }^{133}$ Zob. Księga dochodów.., dz. cyt., s. 138, 146, 158; por. Wizytacje..., dz. cyt., s. 348-350.

${ }^{134}$ Zob. E. P i w o w a r c z y k, Dzieje..., dz. cyt., s. 147; por. J. R a j m a n, Średniowieczne patrocinia..., dz. cyt., s. 65. Jerzy Rajman stwierdza też, iż kaplica ta zwana była kaplica Langmichela. Langmichelem zwany był jednak Michał Czirla, fundator kaplicy Męki Pańskiej. Zob. też: B. K u mo r, Dzieje..., dz. cyt., s. 554. Bolesław Kumor jednak nie podaje uposażenia ministeriów, zaznaczając tylko, iż w kaplicy znajdowały się dwa ołtarze: NPM i Św. Michała.

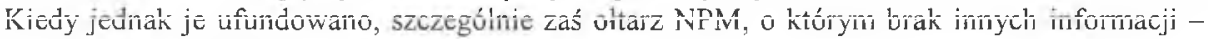
autor bliżej nie określa.

${ }^{135}$ Zob. LB 2, s. 5

${ }^{136}$ W roku 1599 ołtarz ten należał już do Bractwa Kuśnierzy przy kościele Panny Marii zob. Wizytacje..., dz. cyt., s. 365-367.

${ }^{137}$ Zob. E. P i wow a r c zy k, Dzieje..., dz. cyt., s. 147; por. J. R a j m a n, Średniowieczne patrocinia..., dz. cyt., s. 65 (gdzie autor wskazuje na pierwsze źródło odnoszące się do tego ołtarza na dokument $\mathrm{z}$ roku 1446$)$.

${ }_{138}$ Zob. APkM, dypl. nr 31(61) [druk: KDK 2, nr 546], 31(62) [druk: ZDKK 2, nr 487].

${ }^{139}$ Zob. tamże, dypl. nr 32(63) [druk: ZDKK 2, nr 489]. Por. J. R a j ma n, Średniowieczne patrocinia..., dz. cyt., s. 63 ; zob. B. K u mor, Dzieje..., dz. cyt., s. 551, tabela 88 (tam też wzmiankuje wezwanie altarii tylko jako Narodzenia NPM). 
tronat nad tym ministerium sprawowali rajcy krakowscy, którzy również uposażali altarię i mianowali na stanowisko altarysty jednego $z$ wikarych seniorów kościoła Panny Marii; $\mathrm{z}$ ich zapewne prezenty altarystą był w owym czasie bakałarz z Tarnowa ${ }^{140}$. Wkrótce jednak kaplica ta (1473) - nosząca wówczas wezwanie Św. Trójcy - przeszła w patronat Marcina Bełze ${ }^{141}$, a w roku 1491 uposażono przy istniejącym w niej oltarzu II ministerium altarii ku czci Ducha Św. ${ }^{142}$ W roku 1498 oddali też rajcy krakowscy stanowisko altarysty, po śmierci Krystiana z Tarnowa, Pawłowi „de Bogsthad” ${ }^{43}$. II ministerium przy tymże ołtarzu, altarii ku czci Ducha Św., Nawrócenia św. Pawła i Łukasza Ewangelisty, uposażono rocznym czynszem 12 grzywien zabezpieczonym na postrzygalni miejskiej, dopiero w roku 1491, z zapisu księdza Jana Schepera i jego siostry Doroty, żony Eustachego Scholcza (Schulcza) ${ }^{144}$. Być może, iż na to właśnie ministerium zamianowali rajcy krakowscy w roku 1505, po śmierci Grzegorza z Poznania, Jana, wikarego kościoła Panny Marii ${ }^{145}$. W roku 1511 Jan Heydecke, archiprezbiter kościoła Panny Marii, ufundował też przy ołtarzu w kaplicy zwanej Ducha Św. altarię dla kaznodziei niemieckiego, uposażoną czynszem rocznym 40 (!) grzywien, zabezpieczonym na wadze większej i topni ${ }^{146}$. W tym samym roku (1511) zmienił się jednak właściciel kaplicy, którą otrzymał od rady miejskiej - wyprocesowawszy ją do Bełzów - Jan Boner; dwa lata później Boner otrzymal potwierdzenie od papieża Leona X nabycia do kaplicy wszelkich praw ${ }^{147}$. Cztery lata później (1515) nadano też dla tej kaplicy, zwanej niegdyś Ducha Św., a obecnie ŚŚ. Janów Chrzciciela i Ewangelisty $-z$ nowym ołtarzem (ok. 1516) ku czci owych świętych, fundacji Jana Bonera - odpusty, dla tych, którzy złożą datki na jej odnowienie ${ }^{148}$; nadanie odpustów powtórzył papież Leon X w roku $1519^{149}$. Natomiast jeszcze przed rokiem 1529 uposażono III ministerium altarii ku czci św. Stefana i Pawła przy istniejącym w kaplicy ołtarzu ŚŚ. Jana Chrzciciela i Ewangelisty ${ }^{150}$. W tymże też roku w Liber retaxationum zapisano, iż I ministerium uposażone było na domu kuśnierskim (rodziny Tenczerów), altarystą zaś był (od 1528) Mateusz z Biecza ${ }^{151}$. II ministerium, którego altarystą był Jakub z Frankfurtu, uposażał wójt z Linicy; natomiast altarysta III ministerium altarii śś. Jana Chrzciciela i Tomasza Apostoła,

${ }^{140}$ Zob. LB 2, s. 4.

${ }^{14 !}$ Zob. CA 1, nr 617

${ }^{142}$ Zob. APkM, dypl. nr 61(113), 62(114).

${ }^{143}$ Zob. tamże, dypl. nr 72(130).

${ }^{144}$ Zob. KDK 2, nr 602; APkM, dypl. nr 61(113), 62(114); por. tamże, vol. 45, fasc. A. Por. B. K u mo r, Dzieje..., dz. cyt., s. 551, tabela 88 (gdzie autor upatruje fundatora uposażenia II ministerium altarii śś. Stefana i Pawła w osobie księdza Szepte, przed rokiem 1529).

${ }^{145}$ Zob. APkM, dypl. nr 81(140).

146 Zob. Wizytacje.., dz. cyt., s. 383; por. E. D ł u go pols k i, Wstęp..., dz. cyt., s. 16-17.

${ }^{147}$ Zob. APkM, dypl. nr 85(147).

148 Zob. Vetera Monumenta Poloniae Lithuaniae et Vaticana, t. 2, wyd. A. Theiner, Romae 1861, nr 384.

149 Zob. tamże, nr 410.

${ }^{150}$ Zob. APkM, vol. 45, fasc. A. Por. B. K u mo r, Dzieje..., dz. cyt., s. 551, tabela 88. Bolesław Kumor wymienia jednak jako fundatora uposażenia III ministerium mieszczanina Hieronima Powodowskiego, podając dwie daty fundacji: 1476 i 1596 rok. Tymczasem ów mieszczanin był księdzem i to archiprezbiterem mariackim w latach 1585-1613.

${ }^{151}$ Zob. APkM, dypl. 101(175). 
doktor dekretów Erazm z Krakowa, czerpał uposażenie z racji funkcji z sześciu jatek rzeźniczych i jednej piekarni ${ }^{152}$.

\section{FUNDACJE OLTARZY W 2. POLOWIE XV WIEKU}

Jak zatem możemy wnioskować z przedstawionego powyżej stanu wyposażenia wnętrza kościoła Panny Marii w ołtarze, dzięki indywidualnym pobożnościowo-wotywnym zapisom, już w 1. połowie XV stulecia wnętrze świątyni otrzymało swój zasadniczy wystrój. Wobec tak bogatego wyposażenia skromnym musiał się jednak wydawać istniejący od około roku 1365 ołtarz główny, tym bardziej, iż uległ on w pewnym stopniu zniszczeniu, gdy „runęło" sklepienie prezbiterium (1442). Dlatego też, w 2. połowie XV wieku, mieszczaństwo krakowskie podjęło wspólny wysiłek sprawienia nowego ołtarza głównego, który dorównywałby innym, znajdującym się w kościołach krakowskich.

Jeszcze $w$ trakcie trwania prac przygotowawczych nad ołtarzem glownym ustawiono przy tym samym środkowym filarze południowej nawy co ołtarz Sw. Marii Magdaleny w świątyni Panny Marii kolejny ołtarz boczny. Ufundował go około roku 1475 Stanisław Lang, rajca krakowski, pod wezwaniem Męki Pańskiej i Bożej Rodzicielki, a także Św. Anny (Passionis Domini et Deipare V. M. nunc S. Annae) ${ }^{153}$; ołtarz ten, zwany także ołtarzem „Góry Oliwnej”, erygowany został w roku $1480^{154}$. I ministerium przy ołtarzu Meki Pańskiej, altarii pod tym samym wezwaniem co ołtarz, uposażono w roku 1480 na wsi Prądnik ${ }^{155}$. Natomiast w roku 1516 zapisu na tenże ołtarz dokonał Adam Szwarc poprzez rajców krakowskich Kaspra Behema i Pawła Kaufmana, wykonawców jego testamentu; na tej podstawie uposażono I ministerium czynszem rocznym 9 grzywien zabezpieczonym na dobrach Nagórzany, Działoszyce 1 Wrelgasy ${ }^{156}$. W roku zaś 1529 , według Liber retaxationum, altarysta tegoż ministerium, którym był doktor dekretów Filip Hacr z Krakowa, czerpał uposażenie $\mathrm{z}$ racji funkcji z żup bocheńskich i wielic$\operatorname{kich}^{157}$.

Największym jednak przedsięwzięciem, związanym ze zmianą wyposażenia wnętrza w 2. połowie XV stulecia, było sprawienie nowego ołtarza głównego.

${ }^{152}$ Zob. Księga dochodów..., dz. cyt., s. 127, 132, 205; zob. też: APkM, vol. 45, fasc. A; por. Wizytacje..., dz. cyt., s. 343-347.

${ }^{153}$ Zob. E. P i wow a r c zy k, Dzieje..., dz. cyt., s. 157 ; por. J. R a j m a n, Średniowieczne patrocinia.., dz. cyt., s. 201. Zob. też: B. K u m o r, Dzieje.., dz. cyt., s. 543. Bolesław Kumor łączy jednak dwa ołtarze: Św. Marii Magdaleny i Męki Pańskiej w jeden, podając jego fun-

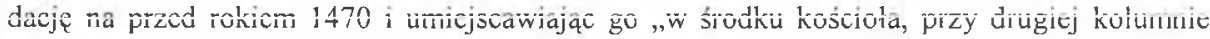
w ogrodzie". Na innym też miejscu wymienia jeszcze inny ołtarz Męki Pańskiej, ustawiony według niego - przy kolumnie w środku kościoła - zob. tamże, s. 544. Właściwy ołtarz Męki Pańskiej znajdował się jednak przy środkowym (nawy południowej) filarze kościoła, tam gdzie ołtarz św. Marii Magdaleny.

${ }^{154}$ Zob. APkM, vol. 45, fasc. A.

${ }^{155}$ Zob. tamże, vol. 55, fasc. 123, nr 2. Por. B. K u mo r, Dzieje..., dz. cyt., s. 544, tabela 82 (gdzie autor podaje, iż fundatorem uposażenia I ministerium altarii śs. Anny i Jakuba był Jan Borg i wymienia dwie daty fundacji 1480 i 1590 rok).

${ }^{156}$ Zob. APkM, dypl. nr 89(153, 154), 90(155).

${ }^{157}$ Zob. Księga dochodów..., dz. cyt., s. 193; zob. też: APkM, vol. 45, fasc. A; por. Wizytacje..., dz. cyt., s. 332-335. 
Kiedy bowiem w roku 1442 uległo znacznemu zniszczeniu sklepienie prezbiterium świątyni, a tym samym uległ również uszkodzeniu znajdujący się tam ołtarz Wniebowzięcia NPM (fundacji Mikołaja Wierzynka Młodszego; ok. 1365), miasto zawarło umowę na odbudowę sklepienia z mistrzem Czipserem z Kazimierza. W zleceniu pracy była jednak mowa nie tylko o zasklepieniu na nowo chóru, ale także o tym, aby ,altare summum adaptare debet inversione lapidis magni marmorei et quibusque reformationibus oportunis" ${ }^{\prime 158}$. Pracę swą w odniesieniu do naprawy ołtarza głównego zapewne Czipser wykonał, chociaż nie wiemy, w jakim stopniu była ona konieczna, a w zwiazku z tym, jak wielkim uszkodzeniom uległ ołtarz główny w roku 1442. Niemniej, pomimo zapewne doprowadzenia XIV-wiecznego ołtarza do odpowiedniego stanu, pojawił się zamiar sprawienia do świątyni Panny Marii nowego ołtarza głównego, który odpowiadałby wymogom czasów.

Nie znamy co prawda nazwiska głównego inicjatora pracy nad nowym ołtarzem mariackim oraz motywu powierzenia jego wykonania snycerzowi Witowi Stwoszowi, aczkolwiek myśl o wystawieniu takowego w krakowskiej farze pojawiła się zapewne jeszcze przed rokiem 1473; od tego czasu pojawiają się bowiem na ten cel zapisane w dokumentach źródłowych legaty ${ }^{159}$. Pięć lat później (1477), przybyłemu do Krakowa z Norymbergi mistrzowi Witowi Stwoszowi powierzono wykonanie głównego ołtarza do kościoła Panny Marii; według aktu erekcyjnego prace trwały 12 lat $(1477-1489)^{160}$. Dla spraw związanych ze wznoszeniem ołtarza rada miejska zamianowała - jak wynika z aktu erekcyjnego ołtarza - specjalnych prowizorów, którzy sprawowali pieczę nad prowadzonymi pracami, a także m.in. odbierali (przynajmniej częściowo) przekazywane na ten cel należności ${ }^{161}$. W ten sposób rada miejska sprawowala rolę kierowniczą w pracach nad ołtarzem, finansowy zaś jej udział (koszt robót wyniósł 2808 florenów), odnotowano we wspomnianym dokumencie jako: ,tamen de praetorio aut aerario publico nihil datum est". ${ }^{162}$ Wykonanie ołtarza sfinansowane zatem zostało zarówno ze zwyczajnych składek i ofiar wiernych (być może, że i od mieszkańców przynależnych

${ }^{158} \mathrm{CA} 1$, nr 377, s. 120 .

${ }^{159}$ Zapewne jednymi z pierwszych ofiarodawców na budowę nowego ołtarza byli w roku 1473: ławnik krakowski Maciej Opoczko (zob. tamże, nr 614) oraz Stanisław Fiszberg (zob. A. G r a b o w s k i, Kraków i jego okolice, Kraków 1866 ${ }^{4}$, s. 365). Trzy lata później (1476), odnotowano też dar Doroty Schusterin (Świeczniczanki) (zob. Archiwum Akt Dawnych miasta Krakowa, rkps 772, s. 120, cyt. za: M. F r i e d b e r g, Ottarz krakowski Wita Stwosza. Studium archiwalne, „Przegląd Zachodni” 8/8:1952 [nadbitka], s. 21).

${ }^{160}$ Tekst aktu erekcyjnego ołtarza nie zachował się $w$ oryginale, lecz $w$ trzech przekazach późniejszych - zob. APkM, vol. 7, fasc. 6; Biblioteka Jagiellońska, rkps nr 107, s. 62; por. CA $1, \mathrm{nr} 1028$.

${ }^{161}$ W skład pierwszego komitetu wchodzili: dwaj radni - Mikołaj Kreidler i Piotr Lang, oraz notariusz miejski - Krzysztof Rebencz z Malborka. Po śmierci członków tego komitetu powołano kolejnych dwóch radnych - Jana Kletnera i Jana Turzo, nowego notariusza miejskiego - Jana Heydeka, oraz przedstawiciela szerszych watstw mieszczaństwa - szklarza Jakuba Glasera. W zapisach ofiar na rzecz ołtarza występują również, jako prowizorowie i członkowie rady: Seweryn Bethman i Jan Schultis. Zob. CA 1, nr 1028.

${ }_{152}$ Tamże. Co prawda, ewentualne udzielenie poparcia finansowego przez miasto mogło wchodzić w grę, jednak brak na ten temat potwierdzenia źródłowego, jako że z 2. połowy XV wieku zachowała się tylko jedna księga rachunkowa (z 1487), a tam nie zanotowano żadnego wydatku na ołtarz mariacki. 
do kościoła Panny Marii - Bronowic), jak i legatów ${ }^{163}$. Był więc główny ołtarz krakowskiej fary, z główną sceną przedstawiającą Zaśnięcie NPM ${ }^{164}$, od strony finansowej, dziełem zbiorowego wysiłku mieszczan krakowskich. Jako uposażenie dla altarystów nowego ołtarza utrzymano wcześniejsze ${ }^{165}$, które odnotowano również w Liber retaxationum z roku 1529 . W owym czasie altarystą I ministerium, nad którym sprawowal patronat niejaki Leonard, był Jan z Lublina czerpiący uposażenie z racji funkcji z żup wielickich i czynszu z domu przy ul. Mikołajskiej; II ministerium, nad którym patronat sprawował Stanisław z Pacanowa, uposażone było na cle krakowskim ${ }^{160}$.

Jeszcze w trakcie trwania prac nad ołtarzem głównym, przed rokiem 1483, wykonano też drugi ołtarz do kaplicy Św. Aleksego. Pod tym bowiem rokiem odnajdujemy w dokumentach wzmiankę o konieczności odnowienia zniszczonej kaplicy i zapisie na ten cel Jana Turzo; on także uposażył sumą 800 złotych węgierskich w złocie ołtarz fundowany przez Urszulę, żonę Jana Beme ${ }^{167}$. Był to ołtarz Wniebowzięcia NPM (Assumptionis B.M.V.), którego altarysta w roku 1529 posiadał własne uposażenie czerpane z piekarni oraz włości Czarnej Wsi pod miastem $^{168}$.

Wkrótce po ukończeniu ołtarza głównego w źródłach odnotowano również wykonanie (z początkiem lat dziewięćdziesiątych XV wieku) do kościoła Panny Marii przez Wita Stwosza dwóch nastaw ołtarzowych. W latach około 1492-1496 wykonał on do ołtarza Św. Krzyża rzeźbę Chrystusa Ukrzyżowanego, na sprawienie której fundację przeznaczył mincerz królewski Henryk Slacker ${ }^{169}$. Natomiast

${ }^{163}$ W źródłach zanotowano, przeznaczonych na oltarz główny do kościoła Panny Marii, dwadzieścia pięć zapisów (w tym dwa sprzed rozpoczęcia prac) wciagniętych do ksiag: testamentów, radzieckiej oraz (zaginioncj) lawniczej, a nadto jeden zapis wskazany przez akt erekcyjny; wśród nich tylko dziesięc stanowi zapisy testamentowe na ołtarz, a i to razem $z$ ofiarami na inne kościoły. Odnośnych datków dokonali: w roku 1478 - mieszczanin krakowski Jan Stano; 1479 - solarz Maciej Muskała, Piotr Lang; 1480 - Jerzy Lang i Jan Krupka, kotlarz Piotr Kopersmistrz; 1482 - Wilhelm, Zuzanna Beck, Elżbieta Wilhelmowa; 1483 - Weronika, żona Jakuba Tale, Piotr Scheptcz (Schepcz), Anna Glejwic, Antoni Avecci z Florencji; 1484 - Bartosz Reich, Franciszek Gliwicz; 1485 - aptekarz Paweł, Jan Gobil; 1486 - Wawrzyniec Gobil, Anna, żona Szymona kapelusznika; 1487 - Katarzyna płatnerka; 1488 - Barbara, wdowa po Kasprze Roth, Małgorzata Szelwowa, Jan Korbel, Anna Bartosz ze swoją siostrą Martą Aptekarka; 1489 - Urszula Eustachiuszowa, kuśnierz Lazarus. Zob. E. P i w o w a r c z y k, Dzieje..., dz. cyt., s. 152 , przyp. 82 .

${ }^{164}$ Nadal jednak oltarz ten nazywany był ołtarzem Wniebowzięcia NPM i pod takim wezwaniem zapisywano go $w$ dokumentach.

${ }^{165}$ Zob. E. P i w o wa r c z y k, Fundacje..., dz. cyt., s. 203-204.

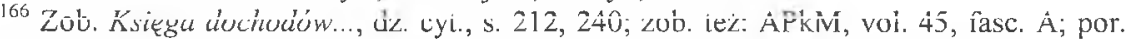
Wizytacje..., s. 289. Por. B. K u m o r, Dzieje..., dz. cyt., s. 538, tabela 75. Bolesław Kumor jednak błędnie łączy uposazenie tego I ministerium - przez niejakiego Leonarda, mieszczanina krakowskiego z roku 1505 - z ołtarzem Przemienienia Pańskiego w kaplicy fundacji Jana Dolnicza.

${ }^{167}$ Zob. CA 1, nr 860.

${ }^{168}$ Zob. Księga dochodów..., dz. cyt., s. 255; zob. też: APkM, vol. 45, fasc. A.

169 Zob. CA 2, nr 74. Możliwe jest, iż ów Krucyfiks wypelnił tylko środkową kwatere tryptyku, boczne zaś zostały wykonane z innych fundacji. W roku 1492 doszło bowiem do sporu pomiędzy altarystą kościoła Panny Marii Jakubem Walendorfem a snycerzem Witem Stwoszem w związku z zapłatą za wykonanie „,nonnullas imagines super tabulam altaris”, za które Stwosz mial otrzymać 28 florenów wegierskich - zob. CA 1, nr 1108,1109, 1115, 1163. W świetle za- 
drugą $z$ nastaw, wykonaną na zlecenie rajców miejskich, ustawiono „przed stallami radzieckimi" - była to nowa nastawa dla oltarza ŚŚ. Szymona i Judy Apostolów (ok. 1495) $)^{170}$.

Mniej więcej w tym też czasie, około roku 1493, z fundacji Emerama Salomona sprawiono ostatni z XV-wiecznych ołtarzy do kościoła Panny Marii - oltarz ku czci Św. Trójcy (SS. Trinitatis), dostawiony do środkowego filaru nawy północnej, gdzie stał już ołtarz Trzech Króli ${ }^{171}$. Przed rokiem 1509 legatu na I ministerium tego ołtarza, altarii ku czci św. Jana Jałmużnika - w pełnym brzmieniu: Św. Trójcy, śś. Jana Jałmużnika i Emerama - dokonał Mikołaj Emeram Salomon (zm. 1509) ${ }^{172}$. Odnotowano go również w Liber retaxationum $\mathrm{z}$ roku 1529 , gdzie zapisano, iż ministerium uposażone było na wsiach: Dobrków, Karkosz, Labuszany [ Labuzie] i Mokrzecz, altarystą zaś był w owym czasie magister Wolfgang ${ }^{173}$.

Wskazane powyżej ołtarze były ostatnimi, jakie - w świetle zachowanych dokumentów źródłowych - ufundowano w XV stuleciu do wnętrzu świątyni Panny Marii. Sprawienie też do krakowskiej fary nowego oltarza głównego świadczyło poniekąd o randze, jaką z końcem tego stulecia osiagnęła świątynia. Nie podlega bowiem wątpliwości specjalna troska o bazylikę społeczności mieszczańskiej Krakowa, której ofiarność najdobitniej uwidoczniła się w przypadku fundacji ołtarzy i uposażania przy altariach ministeriów. Niewatpliwie najwspanialszym z XV-wiecznych ołtarzy - będącym jednocześnie wyrazem wspólnej troski mieszczan o wystrój świątyni - był ołtarz główny Wniebowzięcia NPM (1477-1489), wykonany przez Wita Stwosza (wcześniejsze: Matki Bożej, ok. 1222; Wniebowzięcia NPM, 1365). Kolejne ołtarze umieszczono we wnętrzu korpusu nawowego: przy tęczy po stronie pólnocnej - Zwiastowania NPM (ok. 1433); zamknięciu poludniowej nawy bocznej - Św. Krzyża (przed 1439; nowa nastawa ok. 1492); przy środkowych filarach nawy północnej - Św. Leonarda (ok. 1460), Św. Trójcy

chowanych źródeł byłaby to jcdnak zbyt mała kwota, jak za wykonanie całej nastawy (por. przyp. 170), dlatego też można domniemywać o wykonaniu na zlecenie Walendorfa tylko jednej $\mathrm{z}$ bocznych kwater tryptyku.

${ }^{170}$ Odnośnie do tej nastawy oltarzowej odnotowano w roku 1495 zaplatę w wysokości 150 florenów węgierskich do uiszczenia w ciagu dwóch Jat, którą - jak wynika z noty - rajcy zaplacili - zob. tamże, nr 1204.

${ }^{171}$ Zob. CA 1, nr 1057, 1136, 1139. Zob. też: E. P i w ow a r c zyk, Dzieje..., s. 158; por. J. R a j ma n, Sredniowieczne patrocinia..., dz. cyt., s. 64 (gdzie autor odnotował ołtarz pod wezwaniem altarii I ministerium: św. Jana Jałmużnika). Zob. też: B. K u m o r, Dzieje..., dz. cyt., s. 545. Bolesław Kumor jednak nie wymienia ołtarza Sw. Trójcy, lecz znajdujący się na jego miejscu późniejszy ołtarz Sw. Józefa Oblubieńca NPM, przypisując mu również wcześniejsze ministeria.

${ }^{172}$ Zob. Wypisy źródlowe do dziejów Wawelu1501-1515, wyd. B. Przybyszewski, Kraków 1965 (Źródła do dziejów Wawelu, t. 4), s. XI, przyp. 2. Por. B. K u m o r, Dzieje..., dz. cyt., s. 545, tabela 83 (tam też autor wymienia jako fundatora uposażenia I ministerium przed rokiem 1515 - Piotra Salomona; wskazuje również na uposażenie II ministerium, legowane w roku 1528 sumptem Imbrama [Emerama] z Krakowa).

${ }^{173}$ Zob. Księga dochodów..., dz. cyt., s. 348; por. Wizytacje..., dz. cyt., s. 336, 382-383, $384-385$. 
(ok. 1493; drugi: Trzech Króli, przed 1400), ŚŚ. Szymona i Judy Apostołów (przed 1425; nowa nastawa ok. 1495); przy środkowych filarach nawy południowej - Wniebowzięcia NPM (przed 1443), Sw. Marii Magdaleny (przed 1419) oraz Męki Pańskiej (ok. 1475), Św. Anny (ok. 1433). Następne ołtarze ufundowano do naw bocznych, ustawiając je pomiędzy wejściami do dobudowanych do korpusu nawowego kaplic i krucht: po stronie północnej - Św. Agnieszki (przed 1440), Św. Benedykta (przed 1419); po stronie południowej - Nawiedzenia NPM (1432), Św. Tomasza (przed 1430). Kolejne zaś ozdabiały wnętrza tychże kaplic: Matki Bożej Śnieżnej (ok. 1435), Przemienienia Pańskiego (ok. 1435), Męki Pańskiej (ok. 1435), Zwiastowania NPM (1435), Bożego Ciała (ok. 1439-1441), Św. Trójcy (ok. 1441), Św. Michała (ok. 1443), Wszechmogącego Boga i Narodzenia NPM (1445). Nowe ołtarze sprawiono też do kaplic wieżowych: w przyziemiu wieży południowej - Wniebowzięcia NPM (ok. 1483; drugi: Św. Aleksego, przed 1383); w przyziemiu wieży północnej - Św. Stanisława (przed 1423; wcześniejszy: ŚŚ. Jana Chrzciciela i Zygmunta Króla, przed 1383); w kaplicy Bractwa Wniebowzięcia NPM - Wniebowzięcia NPM (przed 1446; wcześniejszy: Wszechmogącego Boga i Nawiedzenia NPM, ok. 1395).

Z końcem XV stulecia mieszczanie krakowscy mogli juź zatem uczestniczyć w sprawowanych przy ołtarzu głównym lub przy trzydziestu dwóch $(11 \mathrm{z}$ nich ufundowano jeszcze $\mathrm{w}$ XIV stuleciu, 21 zaś $\mathrm{w}$ XV wieku) oltarzach bocznych bądź kaplicowych nabożeństwach. Ołtarze te pochodziły $\mathrm{z}$ pobożnościowowotywnych fundacji mieszczan krakowskich, którzy też swoimi legatami utrzymywali stare i tworzyli nowe altarie oraz uposażali już istniejące i fundowali nowe ministeria.

\section{Funding of $15^{\text {th }}$ Century Altars in St. Mary's Church in Cracow and Providing for their Upkeep till 1529 Summary}

The altars described in the article were the last - according to the preserved records - to be funded in the $15^{\text {th }}$ century inside St. Mary's Church. Procuring a new main altar for the church in Cracow testified, as it were, to the standing that this church gained at the end of the century. There is no doubt whatsoever that Cracow burghers treated the basilica with exceptional care manifested through their generosity when it came to funding altars and providing for ministers at the altars. Unquestionably, the most magnifjcent of all $15^{\text {th }}$ century altars - and one that was at the same time an expression of care of all burghers for the interior decoration of the church - was the main altar of the Assumption of the Virgin Mary (1477-1489 ), made by Wit Stwosz.

At the end of the $15^{\text {th }}$ century Cracow burghers were able to participate in services held at the main altar or any of the 32 side altars ( 11 of which were funded in the $14^{\text {th }}$ and 21 in the $15^{\text {th }}$ century) or in services in chapels. The altars were religious or votive offerings by Cracow burghers, who provided for the old and made new provisions in their legacies as well as maintained the existing ones and made provisions for new ministers. 